\section{BYTOSTNÁ ROLE \\ P̌̌EDPOROZUMĚNÍ U VYBRANÝCH ZAKLADATELŮ KVANTOVÉ TEORIE}

Abstrakt: Článek se zabývá existenciální rolí předporozumèní u vi̊dčích zakladatelu kvantové teorie. V první části článek predstavuje Heideggerovo hermeneuticko-fenomenologické uchopení pojmu rozumèní. Ve druhé části se autor pokouši prostřednictvím rozmanitých príkladi̊ aplikovat tuto koncepci na zpưsob myšlení, s nimž fyzici (Planck, Einstein, de Broglie, Rutherford, Bohr, Heisenberg a Schrödinger) pristupovali $k$ rešení vědeckých hádanek a návrhưm nových předpokladů při vzniku kvantové teorie. Text je př́spěvkem do debat $v$ rámci filosofie a metodologie vědy, v niž je stále podceňována zásadní role predporozumění ve vědeckých aktivitách.

Klíčová slova: kvantová teorie; hermeneutická fenomenologie; Bohr; de Broglie; Heidegger; Heisenberg

\section{An Existential Role of Pre- Understandings in the Leading Founders of Quantum Theory}

Abstract: The study deals with an existential role of preunderstandings in the works of the leading founders of quantum theory. First, the study introduces Heidegger's hermeneuticphenomenological approach to the concept of understanding. Second, this concept is applied to various ways of thinking with which physicists (Planck, Einstein, de Broglie, Rutherford, Bohr, Heisenberg and Schrödinger) approached the solutions of scientific puzzles and constructions of new assumptions in the development of quantum theory. The article seeks to contribute to the debate in the methodology and philosophy of science and points out that the role of preunderstandings is still underestimated.

Keywords: quantum theory; hermeneutic phenomenology; Bohr; de Broglie; Heidegger; Heisenberg

\title{
FILIP GRYGAR
}

Katedra filozofie a religionistiky

Univerzita Pardubice, Fakulta filozofická

Studentská 84, 53210 Pardubice

email / filio@centrum.cz

(iD) 0000-0002-0125-3371

(C) (1) Toto dílo podléhá licenci Creative Commons Attribution 4.0 International. 


\section{1. Úvod}

$\mathrm{V}$ dějinách vědeckého myšlení a rozvoje vědních disciplín hraje kromě náhod, štěstí, intuice a talentu nepostradatelnou roli to, co známý americký fyzik, historik, metodolog a filosof vědy Thomas $S$. Kuhn vměstnal v roce 1962 - ve svém bestselleru Struktura védeckých revolucí - do obsahu dnes již široce užívaného pojmu paradigma. ${ }^{1} \mathrm{O}$ Kuhnově přístupu k vývoji a revolučním proměnám vědy bylo napsáno už nepřeberné množství literatury a jak Kuhn, tak pojem paradigma jako specifické předporozumění, s nímž vědci přistupují $k$ řešení vědeckých hádanek, se stali již standardem v diskutovaných otázkách metodologie, filosofie a historie vědy; jedním $z$ témat je pochopitelně vztah mezi paradigmaty klasické fyziky a kvantové teorie.

Před Kuhnovým pojetím paradigmatu představil už v roce 1927 filosof Martin Heidegger ve svém díle Bytí a čas fundamentálně-ontologickou koncepci rozumění či předporozumění $\mathrm{z}$ hlediska hermeneutické fenomenologie. Ta se v historii a metodologii vědy až na výjimky nepoužívá, což je zjevně dáno nejen stále podceňovanou rolí předporozumění $\mathrm{v}$ našem každodenním a vědeckém životě, nýbrž také Heideggerovým neobvyklým spekulativním vyjadřováním. ${ }^{2}$ Ačkoliv byl kritikem moderní vědy a jejího jednostranného kalkulujícího či technického způsobu myšlení (ne však techniky samotné), jehož vrchol spatřoval v kvantové mechanice, potažmo nukleární fyzice, ${ }^{3}$ za zmínku stojí uvést to, že Heideggerův metodický a epistemologický postoj je blízký některým filosofickým postojům význačného spolutvůrce kvantové teorie, zakladatele univerzitního Fyzikálního ústavu v Kodani a dánského myslitele Nielse Bohra.

Cílem této studie je představit interdisciplinárně zaměřenému čtenáři bytostný rámec předporozumění, jenž ustavuje rozličné kulturní, sociální či psychologické determinace a pohnutky (obecně diskutované v humanitních disciplínách). Také zakladatelé kvantové teorie je spolu s dalšími vědeckými výsledky vědomě $i$ nevědomě přebírali a používali $k$ vysvětlování paradoxních experimentálních dat, navrhování nových pojmů nebo matematických formalismů a také $\mathrm{k}$ jejich různým interpretacím. Nejprve si shrneme a na několika příkladech připomeneme hlavní rysy Heideggerova pojetí rozumění, abychom následně (na rozdíl od četných popularizačních a odborných publikací ke kvantové teorii nebo metodologii

\footnotetext{
${ }^{1}$ Thomas Kuhn, Struktura vědeckých revolucí (Praha: Oikoymenh, 1997).

${ }^{2}$ Martin Heidegger, Bytí a čas (Praha: Oikoymenh, 2002).

${ }^{3} \mathrm{~K}$ tomu viz např. Martin Heidegger, Věda, technika a zamyšlení (Praha: Oikoymenh, 2004), 51.
} 
vědy) nahlédli ontologický status předporozumění, které tedy sehrává existenciální roli nejen v našem každodenním životě, nýbrž také ve vědeckém myšlení.

\section{Heideggerova koncepce rozumění na vybraných př́kladech}

Rozmanitá předporozumění v podobě paradigmat, předsudků (pozitivních i negativních), metafor, percepčních stereotypů nebo temperamentu apod. jsou $\mathrm{v}$ nás zejména $\mathrm{v}$ neuvědomělé rovině zakořeněné prostřednictvím socializace, tj. sociálních vzorců chování a školní nebo vědecké výchovy - ikonické obrázky $\mathrm{v}$ učebnicích nevyjímaje. Všechna tato před- nám umožňují na straně jedné efektivně vykonávat řadu běžných a zautomatizovaných aktivit nebo tzv. normální vědeckou činnost, avšak na straně druhé nám zabraňují v tom, abychom vykročili do neznáma a byli schopni se zamyslet jinak, než jsme zvyklí. Příznačná svázanost $s$ implicitními a explicitními předporozuměními je tak mocná, že např. př́slušnou vědeckou komunitu dlouho vede $\mathrm{k}$ tomu, aby její členové setrvale vysvětlovali hromadící se anomálie podle naučené praxe, eventuálně s ad hoc pomocnými předpoklady, jak správně dokládá Kuhn. Tato paralýza pak přetrvává navzdory tomu, že observační či experimentální evidence je již po nějakou dobu naprosto zřejmá, takže by bylo možné přijmout nové předpoklady, na základě nichž budou mít zkoumané jevy opět vyhovující řešení. Samotný přeskok nebo vykročení $\mathrm{k}$ novému předporozumění a paradigmatu nemá u Kuhna vědecký základ a paradigmatický charakter, nýbrž psychologicko-sociální. ${ }^{4}$

Obrátíme-li se k Heideggerovi, oproti Kuhnově zejména narativnímu a názornému popisu paradigmatických situací nebo rozmanitých prede-, rozebral roli předporozumění v Bytía čase jako záležitost vždy-již existenciální, a to na základě našich bytostných modů či strukturních rysů existence, které nazýval existenciály. Bytostné rysy naší existence však nejsou tradičními nebo klasickými určeními jsoucna zvaného člověk, věc a př́roda $\mathrm{z}$ hlediska idejí, kategorií, substancí, hodnot, duše (mysli, vědomí) nebo reprezentativních pojmů a veličin. Existenciály jsou explikáty, jež podle Heideggera získáváme $\mathrm{v}$ první osobě $\mathrm{z}$ hermeneutického rozboru našeho bytostného rozumění tomu, že jsme, že jest nám být nejen tělesně v hmotném světě, nýbrž že jsme vždy již nedílnou součástí významově zakoušeného světa. Jsme $D a-$ -sein (bytím tu; pobytem), tzn. mistem porozumění bytí či bytí-ve-světě, a této pro Heideggera fundamentálně-ontologické struktuře naší existence vždy

\footnotetext{
${ }^{4}$ Dále viz Kuhn, Struktura vědeckých revolucí, dodatek z roku 1969.
} 
již rozumíme nevýslovně už jen tím, že tak či onak žijeme, aniž bychom to jakkoli reflektovali nebo popisovali. Dále existenciálním smyslem toho, že jest nám v tomto bytostném rozumění bytí-ve-světě tak či onak být, je podle Heideggera starost (die Sorge), nebot at chceme nebo nechceme, v jakýchkoli našich aktivitách se vždy již o sebe staráme, tudíž staráme se o to, že jsme (o naše bytí).

Dalšími Heideggerovými existenciály jsou vedle dimenze rozumění (Verstehen), z něhož se ustavuje konkrétní (ontické, předmětné) porozumění tomu či onomu, také rozpoložení (Befindlichkeit), ze kterého se ustavuje konkrétní nálada (i atmosféra naší doby), nebo řeč (Rede) a smysl (Sinn), z nichž se ustavuje ten či onen vyslovovaný jazyk, včetně jazyka fyzikálního nebo matematického (Sprache), a slova, pojmy či výrazy mající pro nás konkrétní význam (Bedeutung). V Heideggerově pojetí se tak setkáváme s ontologickou a ontickou rovinou rozumění či předporozumění. Ontická rovina je jen interpretačním čili zkonkretizovaným rozvíjením existenciálního rozumění bytí ve světě, o které se staráme. To rovněž znamená, že k tomu vykládanému, popisovanému nebo měřenému už přistupujeme jako subjekt k objektu, tj. provádíme zpředmětňování (objektivizujeme), a tím redukujeme nebo převádíme nezpředmětnitelné rozumění, rozpoložení, řeč nebo smysl na různé interpretační a teoretické úrovně. ${ }^{5}$

U Heideggera se tak nesetkáváme s tradičním nebo školským pojetím hermeneutiky ve smyslu nejprve si vyložíme tuto básničku (vědecký problém), abychom jí (mu) lépe rozuměli. Pro něj naopak platí, že až „rozvinuté rozumění [rozvinutý existenciál - pozn. autora] nazýváme $v y ́ k l a d$ “; jinak řečeno

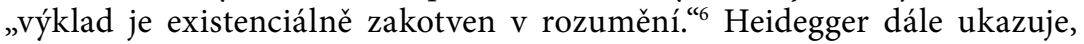
že při jakémkoli chování, aktivování, vysvětlování nebo interpretování (něčeho jakožto něčeho), jsme vždy už bytostně vedeni apriorními rámcem (1) před-se-vzetí (Vorhabe) - z něho vyrůstá naše konkrétní intence nějak se tělesně aktivovat, něco udělat, vyslovit nebo prozkoumat; (2) před-vídání (Vorsicht) - $\mathrm{z}$ něho vyrůstá konkrétně převzaté nebo naučené předporozu-

\footnotetext{
${ }^{5}$ Heidegger, Bytí a čas, $\$ 7,9,12,14,31,32$ a 39 nebo stručné shrnutí na s. 59. Výstižným prŕkladem pro nahlédnutí ontologického pojetí vztahu mezi implicitním a explicitním (konkrétním, naučitelným atd.) rozuměním je slavný výrok Aurelia Augustina z jeho Vyznání o tom, že když se mne nikdo neptá, co je čas (bytí, prostor, dobro, láska, světlo, hmota, realita, vysvětlení atd.), tak vím či rozumím (scio), ruší se zde subjekt-objektové rozlišení. Jakmile však mám o tomto původně zakoušeném rozumění něco vypovědět, tak nevím, respektive provádím jen nesčetné reflexe včetně výkladů vědeckých. Viz Aurelius Augustinus, Vyznání (Praha: Kalich, 2006), XI. kniha.

${ }^{6}$ Heidegger, Bytí a čas, 180.
} 
mění, $s$ nímž mnohdy nevědomky přistupujeme $\mathrm{k}$ tomu, co jsme si předsevzali; a (3) před-pojetí (Vorgriff), z něhož vyrůstá konkrétní pojmový aparát, $s$ nímž ve spjatosti s daným před-vídáním řešíme před-se-vzetí. ${ }^{7}$ Když tedy $\mathrm{v}$ každodenním i vědeckém životě přistupujeme $\mathrm{k}$ něčemu, co se chystáme zkoumat, vysvětlit nebo testovat v experimentu, vždy platí, že „každé tázání je hledání. Každé hledání je předběžně vedeno tím, co hledá." ${ }^{8}$ Současně platí, že jakékoli snahy vyhnout se tomuto nevyhnutelnému hermeneutickému kruhu, vidět $\mathrm{v}$ něm bludný kruh nebo něco dokonce nedokonalého, „znamená zásadně rozumění [jak tomu bytostnému implicitnímu, tak tomu objektivizujícímu či teoretickému - pozn. autora] nerozumět. ${ }^{\text {"9 }}$

Abychom si lépe přiblížili Heideggerovu koncepci rozumění, ukážeme si ještě několik rozmanitých př́kladů - bez ohledu na to, zda se zaměříme na činnosti, které vykonával pravěký, anebo dnešní člověk. Existenciální starost a rozumění tomu, že jsme ve světě, interpretoval a konkretizoval - v rámci předsevzetí, předvídání a předpojetí - pravěký člověk prostřednictvím jeskynních maleb, mýtických a náboženských představ, později $\mathrm{z}$ rozumění našeho bytí a starosti o něj vznikla $\mathrm{v}$ antickém světě geometrie, matematika, filosofie či věda, a od novověku až do současnosti se už jedná o rozmanité specializované obory. Za př́klad z moderní doby si můžeme vzít fyziky z Los Alamos. Víme, že je k sestrojení prvních jaderných bomb dohnal pouze panický strach $z$ toho, že by je pod vedením významného německého fyzika a ctižádostivého patriota Wernera Heisenberga vyrobilo nacistické Německo první. Strach anebo jakákoliv pohnutka, díky které jsme si předsevzali udělat to či ono je také vyjádřením bytí ve světě a existenciální starosti. ${ }^{10}$

Všechny civilizační a společenské proměny nebo vývojové etapy člověka s sebou navíc nesou nepřeberná dějinná a často velmi odvážná rozhodnutí, s nimiž nastupovala a nastupují nová předsevzetí, předvídání a předpojetí respektive nová předporozumění toho, že se rozmanitě staráme o bytí ve světě, a taková rozhodnutí byla a jsou metafyzická, nikoli vědecká. V dějinách vědy platí, že vědci byli vždy schopni v důležitých momentech nebo přechodových událostech učinit zásadní dějinná rozhodnutí, a současně $\mathrm{v}$ jiných situacích lpět dogmaticky na stávajících předpokladech nebo před-

\footnotetext{
${ }^{7}$ Heidegger, Bytí a čas, 182. K rozboru tohoto existenciálního celku dostatečnosti, z něhož rozumíme př́ručnímu jsoucnu, viz $\$ 18$.

${ }^{8}$ Heidegger, Bytí a čas, 20.

${ }^{9}$ Ibid., 185.

${ }^{10}$ Více viz Filip Grygar, „Odvrácená strana legendy: Otto Hahn v kontextu nacistického Německa," Teorie vědy / Theory of Science 41, č. 1 (2019): 60-61.
} 
porozuměních, včetně používání vybraných - a nikoli jiných - technických postupů, vzorků, laboratorních pomůcek, přístrojů atd. Jinak řečeno s Heideggerem, oproti každodennímu a vědeckému zpředmětňujícímu (objektivizujícímu) myšlení, založeném na nesčetných předporozuměních, existuje bytostné zamyšlení, $\mathrm{tj}$. „odvaha učinit tím nejproblematičtějším pravdivost našich předpokladů a oblast, $v$ níž leží cíle našeho usilování. “11

Revoluci v interpretaci existenciálního rozumění tomu, že jest nám být ve světě, přineslo dozajista novověké striktně subjekt-objektové myšlení, v němž začala hrát výsadní roli matematika. Avšak matematika pochází, jak ukazuje Heidegger, z řeckého to mathéma, ta mathémata čili z toho, co člověk „při zkoumání jsoucího a při zacházení s věcmi ví již předem: o tělesech ví, co je tělesovost, o rostlinách, co je rostlinnost, o zvíratech, co je zvířeckost, o lidech, co je lidskost. ${ }^{{ }^{12}} \mathrm{~K}$ této předem známosti, tj. tomu matematickému, také náleží čísla nebo počty. Podle Heideggera je matematika, jak ji známe i dnes, ,jen určitým vyformováním matematična“, čili matematično není redukovatelné na konkrétní matematiku, nebot je obecně to ",na' věcech, co vlastně už známe, co tedy nezískáváme teprve z věcí, ale co si jistým způsobem sami přinášíme s sebou. ${ }^{\text {"13 }}$ Vzhledem $\mathrm{k}$ tomu, že matematika je z naší předem známosti tou nejznámější, naučitelnou, a tudíž i vyučovatelnou, stala se postupně $\mathrm{v}$ novověku dominantním předporozuměním naší starosti o bytí a $\mathrm{v}$ rámci tohoto nového předsevzetí, předvídání a předpojetí i mocným nástrojem při dobývání prrírody.

Jelikož je pro Heideggera moderní fyzika ve své podstatě (bytnosti) věda jednak výzkumná, tzn. že si pro př́rodu vytvořila předem zajištěný „základní rozvrh toho, co jsou př́rodní procesy,“ a jednak matematická, „jedině proto může být experimentální "14 a současně zásadně odlišná od nevýzkumného charakteru či předporozumění poznávání věcí samých (experientia; experimentum) $\mathrm{v}$ antice a středověku. $\mathrm{V}$ důsledku novověkého rozvrhu př́rody, pro moderní fyziku platí, jak uvádí zase Hans-Georg Gadamer, že v tomto

${ }^{11}$ Martin Heidegger, Věk obrazu světa (Praha: Oikoymenh, 2013), 11. Zamýšlející myšlení (das besinnliche Denken) jsou formy přemítavého myšlení hledajícího smysl, tj. myšlení neobjektivní a předpredikativní, které čerpá z dimenze, v níž se smysl rodí. Více viz Martin Heidegger, „Gelassenheit - Zdrženlivá uvolněnost (30. října 1955),“ Filosofický časopis 49, č. 1 (2001): 70-79.

${ }^{12}$ Heidegger, Věk obrazu světa, 11.

${ }^{13}$ Heidegger, „Novověká matematická př́rodní věda,“ 76,83 .

${ }^{14}$ Heidegger, Věk obrazu světa, 10, 14. Více viz tamtéž a dále viz Heidegger, „Novověká matematická prŕrodní věda“ nebo Grygar, Kritika založení galileovské vědy v Husserlově „Krizi evropských věd a transcendentální fenomenologii“ (Červený Kostelec: Pavel Mervart, 2005). 
předporozumění „zkušenost není ani užitečná, a už vůbec ne nezbytná. “15 Kuhnovsky řečeno, tato změna paradigmatu - od aristotelského kvalitativního poznávání prŕrody $\mathrm{k}$ novému konstruktivnímu zkoumání přírody rovněž umožnila vidět misto každodenně zakoušeného kývajícího se lustru vědecky pojaté kyvadlo, místo prkna nakloněnou rovinu, misto vzduchu kyslík a misto červeného jablka specifický soubor atomů a elektromagnetického záření o určitých vlnových délkách atd. ${ }^{16}$

Uved'me si ještě příklad předsevzetí, předvídání a předpojetí u zakladatele moderní vědy potažmo klasické fyziky Galilea Galileiho. Vedle Heideggera jej obšírně rozebírá také filosof a zakladatel fenomenologie Edmund Husserl. Galilei sice v jednom ohledu geniálně odhalil převratnou možnost totální matematizace př́rody, redukující zakoušenou skutečnost na pouhou spočitatelnost, ale zároveň tím $\mathrm{v}$ jiném ohledu zakryl možnost zkoumat př́rodu jako prvotně kvalitativně zakoušenou. Oproti řeckým atomistům, kteří chtěli proniknout na základě matematiky $\mathrm{k}$ nejzazším počátkům (či podstatě jsoucího), jež nemají nebo nemusí mít matematickou povahu, Galilei si předsevzal postulovat nové předporozumění bytí ve světě, tj. matematickou povahu př́rody jako fakt, aniž by uvažoval o tom, že by svoji hypotézu měl dokázat anebo zda ji lze vůbec dokázat. Galileiho reduktivní koncepce skutečnosti či bytí rovná se být měřitelným objektem. ${ }^{17}$ Heidegger v této souvislosti také cituje údajné prohlášení fyzika Maxe Plancka o tom, že „skutečné je to, co je měřitelné.“18

Stejně tak se podařilo Galileimu sestoupit pod každodenně a relativně zakoušenou skutečnost při myšlenkové koncepci fyzikálního pojetí volného pádu a setrvačnosti. Současný matematik, fyzik a filosof Ladislav Kvasz uvádí, že když Galilei např̀. „došel k závěru, že ve skutečnosti jsou pohyby setrvačné a jejich zastavení je pouze důsledkem tření, opouští fyzika oblast

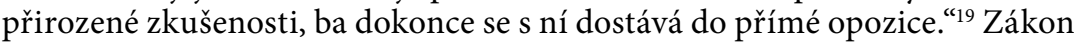
setrvačnosti jakožto geniální metafyzickou tezi vyslovil Galilei následovně:

${ }^{15}$ Hans-Georg Gadamer, Člověk a řeč (Praha: Oikoymenh, 1999), 11. K Heideggerově pojetí matematična viz Aleš Novák, „Heideggerův výklad pojmu mathéma a mathématického charakteru novověké vědy," Teorie vědy / Theory of Science 32, č. 1 (2010): 19-35.

${ }^{16}$ Více viz Kuhn, Struktura vědeckých revolucí, X. kap.

${ }^{17} \mathrm{~K}$ tomuto tématu podrobně viz Filip Grygar, Kritika založení galileovské vědy; Martin Heidegger, „Novověká matematická prŕírodní věda,“ Scientia \& Philosophia, č. 6 (1994): 78-85; Edmund Husserl, Krize evropských věd a transcendentální fenomenologie, Úvod do fenomenologické filosofie (Praha: Academia, 1996).

${ }^{18}$ Heidegger, Véda, technika a zamyšlení, 48.

${ }^{19}$ Ladislav Kvasz, „Galileovská fyzika ve světle Husserlovy fenomenologie,“ Filosofický časopis 48, č. 3 (2000): 389. 
„Myslím si [mente concipio] těleso vržené po horizontální rovině a každou překážku vyloučenou: pak vyplývá $\mathrm{z}$ toho, co bylo obšírně řečeno na jiném místě, že pohyb tělesa po této rovině by byl rovnoměrný a ustavičný, jestliže by se rovina táhla do nekonečna." ${ }^{20}$

Heidegger o jeho průlomovém předporozumění hovoří jako o mente concipere novověkého rozvrhu věcnosti věcí, „který takříkajíc přes věci pře-

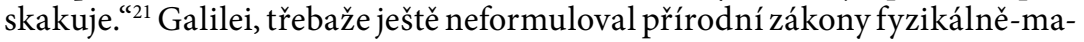
tematicky, vytvořil představu předem ustaveného rozvrhu vesmíru, za nímž nebo v němž se skrývá jen čistá propočitatelná a měřitelná struktura, jež zpětně každý relativně prožívaný nebo kvalitativně zkoumaný př́rodní jev exaktně určuje. Toho lze podle Galileiho docílit prostřednictvím rafinované idealizace $\mathrm{v}$ experimentu. Tudíž u jevů, u nichž není možná přímá matematizace, jako např. u prožitku atmosférického tlaku nebo u vnímání exaktního průběhu volného pádu (naše smysly neregistrují zrychlení u padajícího kamene), je třeba použít experiment, v němž se má daný jev posléze ukázat ve své matematické čistotě. ${ }^{22}$ To podle Kvasze znamená, že „experiment, vytvořením umělé situace, $v$ které je ideální podstata jevu př́stupná prrímému pozorování, vrhá světlo na situace, v kterých je ideální podstata jevu skrytá.“ Novátorský Galileiho př́stup tak „považuje za přirozenost těles cosi, co nikdo nikdy neviděl.“23 Tímto moderním předporozuměním či rozvrhem zkoumání a interpretačním př́stupem $\mathrm{k}$ tomu, že jest nám být ve světě, se má nadále odhalovat jádro jevu čili empirický zákon popsatelný matematickým jazykem. ${ }^{24}$ Tatáž metafyzická představa o podstatě prírodních jevů platí samozřejmě i pro zákon setrvačnosti, jenž se stal až u Isaaca Newtona prvním pohybovým zákonem, který nelze vůbec nijak zkušenostně dokázat (i světlo se zakřivuje a zpomaluje). ${ }^{25}$

Ve škole jsme se učili, že Galilei přišel na zákon volného pádu na základě nakloněné roviny. To ovšem $\mathrm{z}$ výše uvedených důvodů není ani polovičatá výpověd', poněvadž Galilei si předsevzal vyvrátit Aristotelovo kvalitativní

${ }^{20}$ Galileo Galilei v českém překladu viz Heidegger, „Novověká matematická přírodní věda,“ 96. V originále viz Galileo Galilei, Discorsi e Dimostrazioni Mathematiche intormo à Due Nuove Scienze attenenti alla Meccanica, et ai Movimenti Locali (Leida: Ludovico Elzeviro, 1638), 236.

${ }^{21}$ Heidegger, „Novověká matematická prŕírodní věda,“ 98.

${ }^{22}$ Grygar, Kritika založení galileovské vědy, část první, II. kap. Dále k povaze novověké vědy jako moderního výzkumu viz Heidegger, Věk obrazu světa.

${ }^{23}$ Kvasz, „Galileovská fyzika,“ 386, 391.

${ }^{24}$ Ke slavnému Galileově citátu o filosofii napsané v knize vesmíru, jež je sama zapsaná jazykem matematickým, viz Galileo Galilei, Prubiŕr (Praha: Togga, 2020): 127.

${ }^{25}$ Isaac Newton, Matematické principy prórodní filosofie (Praha 2020: Fontes scientiae), 145. 
pojetí pohybu a navrhnout pojetí nové, čistě mechanické. Nejprve si volný pád na základě totální matematizace př́rody (předvídání a předpojetí) v hlavě koncipoval a pak s tímto předporozuměním přistupoval ke vhodnému výběru pomůcek a zlepšování svých pokusů či experimentálních podmínek (eliminovat vliv prostředí, měřit nevnímatelný čas zrychlení různě těžkých koulí na čím dál více nakloněné rovině aj.). Heidegger vystihuje různost předporozumění, s nimiž aristotelici a jejich oponent Galilei přistupovaly $\mathrm{k}$ tomu, že jest nám být ve světě, a tudíž i různost interpretací ohledně toho, co má platit za věcnost věcí u faktu volného pádu, následovně: „Jak Galilei, tak jeho odpůrci viděli totéž ,faktum'; avšak totéž faktum, totéž dění si různě ozřejmovali, různě vykládali. To, co se jim ukazovalo jako vlastní skutečnost a pravda, byly různé věci. On i oni si při témže zjevu [očima vidíme, že těžší tělesa padají k zemi rychleji než lehčí - pozn. autora] něco mysleli, ale mysleli si něco různého, a to ne $v$ jednotlivém, nýbrž zásadně ohledně bytí tělesa a povahy jeho pohybu." ${ }^{\prime 26}$

Historik a filosof vědy Alexandre Koyré v této souvislosti tvrdí, že „dobrá fyzika je a priori. Teorie předchází fakt. Zkušenost je zbytečná, poněvadž před jakoukoliv zkušeností máme již ve vlastnictví takové poznání, které hledáme. ${ }^{“ 27} \mathrm{~K}$ tomu je však třeba dodat, že specifická vědecká zkušenost je potřebná pro technický i teoretický rozvoj toho, co si vědci předsevzali. Totiž $\mathrm{v}$ novém předporozumění totální matematizace přírody probíhá mezi paradigmatickým způsobem fyzikálního myšlení a zlepšujícím se experimentováním či vyráběním výkonnějších přístrojů hermeneutický kruh, v němž se ustavuje moderní vědecká zkušenost. Jedno nemůže být bez druhého a kromě toho vědci získávají další zkušenosti během diskusí mezi sebou navzájem anebo i prostřednictvím rozmanitých inspirací z každodenního života.

\section{Problém deskripce reality}

Interdisciplinárně a filosoficky založený fyzik Niels Bohr si uvedené souvislosti a otázku implicitního a explicitního předporozumění, s nímž vědci vždy již přistupují ke svému zkoumání, uvědomoval, ačkoliv se fenomenologií nezabýval. Opakovaně např. zdůrazňoval, že smyslem fyzikálních oborů (nebo jiných disciplín) není - a ani být nemůže - zjištění, co je neživá př́ŕroda nebo

\footnotetext{
${ }^{26}$ Heidegger, „Novověká matematická přírodní věda,“ 97.

${ }^{27}$ Alexandre Koyré, Metaphysics and Measurement - Essays in Scientific Revolution (Cambridge, MA: Harvard University Press, 1968), 13.
} 
tzv. objektivní realita, protože fyzika a fyzici v první osobě se zabývají jen tím, „co dokážeme říci o prŕrodě. “28 Ani v biologických oborech nelze podle Heideggera a Bohra odpovědět na otázku (de facto zbytečnou) po tom, co je život, nebo co jsou živé organismy, nýbrž jen systematicky zkoumat to, jaké postavení zaujímají v našem zakoušení, respektive „v našem obraze světa.“ ${ }^{29}$

Objektivní realitu jako nezávislou, reprezentativně a kauzálně poznatelnou bránili klasičtí fyzici na základě novověkých filosofických předporozumění vědy a př́rody, Plancka a Alberta Einsteina nevyjímaje. ${ }^{30} \mathrm{Byl}$ to zejména Einstein, jenž až do smrti kritizoval kvantovou teorii za to, že rezignovala na komplexní reprezentativní popis objektivní reality. Einstein si často ve své kritice vypomáhal tzv. myšlenkovými experimenty, jež jsou další ukázkou myšlenkových návrhů (mente concipere) v rámci předsevzetí, předvídání, předpojetí. Tyto experimenty bylo možné prakticky realizovat až po několika desetiletích; nejslavnější z nich je Einstein-Podolsky-Rosen experiment (tzv. EPR experiment) z roku 1935, který nakonec potvrdil závěry kvantové teorie (proto se rovněž nazývá EPR paradox). Naopak Bohr těmto vědcům všechny jejich argumenty ke kritice závěrů kvantové mechaniky vyvracel nejen na základě předporozumění filosofickým důsledkům kvantové teorie, nýbrž také později na základě nahromaděné experimentální evidence. $^{31}$

Z jiného úhlu pohledu v roce 1927 poukazoval Heidegger na to, že je pro něj nepochopitelné, proč někdo stále požaduje nějaký důkaz o vnější existenci věcí či reality mimo nás $s$ jejími údajně nezávislými vlastnostmi a uvedl, že „,skandál filosofie“ nespočívá v tom, že tento důkaz nebyl dosud podán, nýbrž v tom, že takové důkazy jsou stále očekávány a že se o ně znovu

\footnotetext{
${ }^{28}$ Niels Bohr citován dle Aage Petersen, „The Philosophy of Niels Bohr,“ Bulletin of the Atomic Scientists 14, no. 7 (1963): 12.

${ }^{29}$ Niels Bohr, Collected Works, vol. 6, 300. K paralele mezi Bohrem a Heideggerem z hlediska promýšlení fenoménu živého viz Filip Grygar, „Bohr’s Complementarity Framework in Biosemiotics," Biosemiotics 10, no. 1 (2017): 33-5.

${ }^{30}$ Není od věci upozornit rovněž na to, že karteziánská tradice a s ní přírodní vědy včetně Einsteina nesprávně vykládají nebo vůbec neznají Descartův (Kartéziův) pojem realitas obiectiva, který neznamená něco na nás nezávislého, nýbrž předmětnou věcnost idejí v našem vědomí. Více viz René Descartes, Meditace o první filosofii (Praha: Oikoymenh, 2003), 138.

${ }^{31}$ Albert Einstein, Boris Podolsky, and Nathan Rosen, „Can Quantum-mechanical Description of Physical Reality be Considered Complete?"“ Physical Review 47, no. 10 (1935): 777-80; Niels Bohr, „Can Quantum-mechanical Description of Physical Reality be Considered Complete?,“ Physical Review 48, no. 8 (1935): 696-702 nebo též Niels Bohr, Collected Works, vol. 7 (Amsterdam: North-Holland Publishing Company, 1972-2008), 292-98. Viz také Niels Bohr, „Discussion with Einstein on Epistemological Problems in Atomic Physics, "in Bohr, Collected Works, vol. 7, 340-81.
} 
a znovu někdo pokouší، “" $\mathrm{V}$ Heideggerově pojetí rovněž nejsme novověkým uzavřeným karteziánským subjektem, jenž si je vědomý sebe sama ze sebe, nezávisle na vnějším světě. $S$ tímto postojem souzní i Bohrova filosofie vědy.

Bohra k pozitivní rezignaci na možnost poznání objektivní reality vedlo mimo jiné přesvědčení, že sebesofistikovanější teorie o živé a neživé přírodě s nárokem na komplexnost deskripce nejsou schopny plně definovat ani to, co znamená pojem našeho porozumění či vysvětlení. Totiž „rozbor samotného pojmu vysvětlení by přirozeně začal a skončil zřeknutím se vysvětlení vlastní vědomé aktivity “" ${ }^{33}$ Ta při jakékoliv naší jiné aktivitě neustále působí, nelze ji zahrnout do celkového výkladu pojmu vysvětlení, poněvadž je implicitním a apriorním východiskem jakéhokoliv zpředmětňování. To platí i pro problém interakce $\mathrm{v}$ procesech měření, poněvadž „prrístroje nemohou být

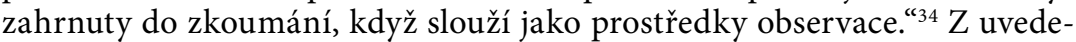
ného důvodu se máme zaměřit především na fundované „zkoumání podmínek pro řádné použivání našich konceptuálních prostředků vyjadřování. “35 Bohr svoji pozici, jak vzpomíná jeho poslední asistent, opětovně připomínal tím, že „závisíme na našich slovech,“ jsme totiž „zachyceni v jazyce [v Bytí a čase je to implicitní dimenze řeči, do níž jsme vrženi - pozn. autora].“ Proto je zbytečné se zabývat tzv. nezávislou realitou, která by ze své podstaty měla jaksi předcházet naší obecně sdílené jazykovosti, nebở už sám předmětný či vyslovený pojem „,realita je také slovo, slovo, které se musíme učit správně používat. ${ }^{{ }^{36}}$ Heisenberg po vzoru Bohra správně uvádí - konkrétně pro částice -, že přeci „zákony prŕrody, které v kvantové teorii matematicky formulujeme, se nezabývají částicemi o sobě, nýbrž naším věděním o elementárních částicích. “"

Podle Heideggera to pochopitelně znamená, jak bylo uvedeno, že sebelepší vysvětlení, popis nebo „výklad nikdy není předpokladu prosté uchopení něčeho daného“" poněvadž je jakýkoli výklad za prvé „vždy zakotven v určitém před-vídání, jež tomu, co si před-se-vzetí před-se-vzalo, „nastřihne“ určitou vyložitelnost“ a za druhé „výklad se již vždy, bezvýhradně nebo s výhradami, pro určité pojmy rozhodl; je založen na určitém před-pojetí. “38

\footnotetext{
${ }^{32}$ Heidegger, Bytí a čas, 240.

${ }^{33}$ Bohr, Collected Works, vol. 10, 35.

${ }^{34}$ Ibid., 31.

${ }^{35}$ Ibid., 112.

${ }^{36}$ Niels Bohr citován dle Petersen, „Philosophy of Niels Bohr,“ 10-11.

${ }^{37}$ Werner Heisenberg, „The Representation of Nature in Contemporary Physics, “Daedalus 87, no. 3 (1958): 99-100.

${ }^{38}$ Heidegger, Bytí a čas, 182.
} 
Jinak řečeno celý život neustále něco interpretujeme jako něco (Etwas als Etwas), tužku jako pisátko, tužku jako štourátko, vypichovátko nebo předmět doličný atd. anebo něco neustále př̀evádíme na něco i když nejde o totéž. Vždy však platí, že „výklad něčeho jako něčeho je bytostně fundován před-se-vzetím, před-vídáním a před-pojetím. “" ${ }^{39}$ To se samozřejmě týká i interpretace reality či atomárního dění.

Každodenně i ve vědě vysvětlujeme nebo transformujeme jakékoliv naše prožitky prožívaného, pozorování pozorovaného na staticky uchopitelný objekt naší reflexe. Jakmile se totiž „snažíme analyzovat naše vlastní emoce, prrestaneme je prožívat ${ }^{\text {" }}{ }^{0}$ a jakmile se to původně zakoušené nebo pozorované stane pouhým (statickým, neživoucím) objektem popisu, už to není totéž. Např. v tradici metafyziky filosofové převáděli bytí na něco, co bytí není (na nejvýše jsoucí ideje, do oblasti logu či kategorií atd.), fyzici redukují vnímání barev na měřitelné vlnové délky a neurovědci zase převádějí prožívání hudby na míru okysličování krve v mozku detekovaného v magnetické rezonanci atd. Vzhledem $\mathrm{k}$ tomu, že vědecká aktivita je naším výkonem, jsou podle kvantového teoretika a filosofa Patricka Heelana i samotné akty „měření hermeneutickým představením, podobně jako to platí pro hraní či opakování nějaké hry, nebo jako je hudební a divadelní představení. “41

$\mathrm{Z}$ existenciálního hermeneutického kruhu se sice vymanit nikdy nelze, ale lze se s ním správně naučit filosoficky pracovat. Heidegger si v tomto směru cenil i některých vědeckých kapacit. Za prŕklad dával Bohra a Heisenberga, kteří „myslí veskrze filosoficky a jen proto jsou s to položit problémy novým způsobem a především v problematičnosti vydržet. ${ }^{\text {“42 }}$ Právě u kvantové teorie se podle Bohra plně ukázalo, že pro nové porozumění zkoumaným jevům (předsevzetí) bylo nutné se obrátit i ke zcela odlišným nefyzikálním oborům a nadto $\mathrm{k}$ filosofickým nebo epistemologickým problémům (předvídání a předpojetí), „s nimiž už byli konfrontováni myslitelé jako Buddha nebo Lao-c', když se pokoušeli harmonizovat naši pozici jakožto diváků a herců ve velkém dramatu existence [jinde našeho bytí - pozn. autora]." ${ }^{“ 3}$

\footnotetext{
${ }^{39}$ Ibid.

${ }^{40}$ Bohr, Collected Works, vol. 10, 245.

${ }^{41}$ Patrick A. Heelan, „Afterword,“ in Hermeneutic Philosophy of Science, Van Gogh's Eyes, and God, Essays in honor of Patrick A. Heelan, S. J., ed. Babette Babich (Dordrecht: Kluwer Academic Publishers, 2002), 450.

${ }^{42}$ Heidegger, „Novověká matematická př́rodní věda,“ 77.

${ }^{43}$ Bohr, Collected Works, vol. 10, 60.
} 


\section{Dualismus záření a hmoty}

$\mathrm{Na}$ konci 19. století se vědci během pokusů s tělesy vyzařujícími anebo pohlcujícími různé druhy záření (na různých frekvencích či vlnových délkách) potýkali s paradoxními výsledky, které nebylo možné plně začlenit do stávajícího předporozumění př́rodních jevů. Od počátku 20. století se kvůli tomu začal ustavovat nový výklad založený na novém předsevzetí, předvídání a předpojetí či předporozumění, jež se čím dál více příčilo klasickým př́rodovědným ideálům logiky, kontinuity, determinismu, kauzality nebo vzájemné odvoditelnosti veličin. V kvantové teorii se jedná primárně o převratné duální pojetí záření (světla), hmoty či atomárního dění a zavedení statisticky pravděpodobnostního charakteru přírodních jevů. ${ }^{44}$ Heisenberg přirovnával tento rozhodující přechod od klasické fyziky ke kvantové k objevení Ameriky Kryštofem Kolumbem v 15. století: „Nejtěžším na této objevné cestě bylo jistě rozhodnutí [Entschluss] opustit dosud známou zemi [novověké předporozumění vědy a klasické předpoklady fyziky - pozn. autora] a plavit se tak daleko na západ, že se zásobami, které měli k dispozici, nebyl možný návrat." ${ }^{45}$

Byl to nejprve tradičně nebo klasicky uvažující fyzik Planck, který položil v památném roce 1900 základní kámen k ustavení nového předporozumění prírody v rodící se kvantové teorii. Dospěl k rozhodnutí, že je už potřeba navrhnout u problematických výsledků se zářením černého tělesa (ideální těleso) nové vysvětlení: oproti klasickým předpokladům navrhl, že energie záření nejen nemůže být na všech frekvencích kontinuálně nekonečně velká anebo naopak malá až nulová, ale rovněž že je dávkována po elementárních akcích, prvcích neboli kvantech (název foton se používá až od roku 1926). ${ }^{46}$ Opuštění tradičních předpokladů (předvídání a předpojetí) a rozhodnutí (předsevzetí) vytvořit nové porozumění byla pro Plancka situace psychicky

\footnotetext{
${ }^{44}$ Více viz Grygar, Komplementární myšlení Nielse Bohra v kontextu fyziky, filosofie a biologie a detailně viz Jagdish Mehra and Helmut Rechenberg, The Historical Development of Quantum Theory, 6 vols. (New York: Springer, 1982-2001).

${ }^{45}$ Werner Heisenberg, Ćást a celek - Rozhovory o atomové fyzice (Olomouc: Votobia, 1996), $85-86$.

${ }^{46}$ Planck své závěry přednesl nejprve 19. ř́ína a pak podrobněji 14. prosince 1900 před Německou fyzikální společností. Viz Max Planck, „Über eine Verbesserung der Wien'schen Spektralgleichung," Verhandlungen der Deutschen Physikalischen Gesellschaft 2, no. 2 (1900): 202-4 (řeč z 19. ř́ina 1900). Dále viz Max Planck, „Zur Theorie des Gesetzes der Energieverteilung im Normalspektrum," Verhandlungen der Deutschen Physikalischen Gesellschaft 2, no. 2 (1900): 237-45 (řeč ze 14. prosince 1900).
} 
dosti nepř́ijemná - akt zoufalství, jak píše v jednom dopise. ${ }^{47}$ Musel totiž pro odvození vyzařovacího zákona využít něco zcela neklasického, tj. jím upravenou statistickou metodu, a navíc, jak zase uvedl v nobelovské přednášce, o filosofických a fyzikálních důsledcích svého počinu pochyboval: „Bud” kvantum akce [jednoduše Planckova konstanta - pozn. autora] byla fiktivní kvantita, potom celá dedukce o radiačním zákoně byla $\mathrm{v}$ podstatě iluzorní a nereprezentovala nic než nějakou prázdnou bezvýznamnou rovnicovou hrátku, nebo byla derivace radiačního zákona založena na nějaké spolehlivé fyzikální představě. V tomto prŕpadě by kvantum akce muselo hrát fundamentální roli ve fyzice, být něčím veskrze novým, dosud neslýchaným, co by patrně volalo po základní revizi veškerého fyzikálního myšlení, které bylo vystavěno od doby ustavení infinitezimálního počtu Leibnizem a Newtonem, na základě přijetí kontinuity veškerých kauzálních spojitostí." ${ }^{48}$

Po Planckově dávkovacím předpokladu (kvantové hypotéze) u záření černého tělesa př̀edstavil Einstein v letech 1905-1909 další netradiční překvapení. Rozhodl se totiž zaměřit (předsevzetí) i na otázku záření probíhajícího ve volném prostoru. Navrhl k tomu matematický propočet, jenž pracoval s duální povahou záření śírícího se jak v podobě vln, tak v podobě světelných částic či kvant (nové předvídání a předpojetí). ${ }^{49}$ Jenže neopomněl zdůraznit, že tyto podivné vlnové a částicové představy by „neměly být nahlíženy jako vzájemně neslučitelné, " ${ }^{50}$ tudíž podle něj bylo nutné nalézt v budoucnu vysvětlení reálné, klasické a tradičně logické. Oba vědci totiž věřili, že jak kvantová hypotéza pro vyzařovací zákon (obdařený Planckovou konstantou), tak absurdní dualismus světla jsou jen prozatímními navrženými matematickými triky, jež bude jednou možné vysvětlit konzistentně na základě klasických předporozumění. Leč situace se vyvíjela zcela odlišným způsobem.

\footnotetext{
${ }^{47}$ Max Planckův dopis Robertovi W. Woodovi 7. ř́jna 1931. Viz Mehra and Rechenberg, The Historical Development of Quantum Theory, vol. 1, 49, 50.

${ }^{48}$ Více viz Max Planck, „The Genesis and Present State of Development of the Quatnum Theory," Nobel Lecture, June 2, 1920. https://www.nobelprize.org/prizes/physics/1918/planck/ lecture/.

${ }^{49}$ Albert Einstein, "Theorie der Lichterzeugung und Lichtabsorption," Annalen der Physik 325, no. 6 (1906): 199-206. Viz také Albert Einstein, „Zum gegenwärtigen Stand des Strahlungsproblems, "Physikalische Zeitschrift, 10, no. 6 (1909): 185-93. V této studii kromě jiného popsal matematicky dualitu částice a vlny pro záření černého tělesa. Dále viz Albert Einstein, „Über die Entwicklung unserer Anschauungen über das Wesen und die Konstitution der Strahlung," Physikalische Zeitschrift, 10, no. 22 (1909): 817-25.

${ }^{50}$ Einstein, „Über die Entwicklung unserer Anschauungen,“ 825.
} 
Humorně absurditu v chápání světla popsal v roce 1921 fyzik William L. Bragg: „V pondělky, středy a pátky používáme vlnovou teorii; $v$ úterky, čtvrtky a soboty uvažujeme $\mathrm{z}$ hlediska proudu letících energetických kvant či korpuskulí. " ${ }^{51}$ Jenže dualismus světla jako nové předporozumění př́rody byl skutečně potvrzen experimentálně v roce 1923 Arthurem H. Comptonem. ${ }^{52}$ Tento experiment okomentoval Einstein slovy: „Takže nyní máme $\mathrm{k}$ dispozici dvě teorie světla, obě jsou nepostradatelné [...] a neexistuje mezi nimi jakákoli logická spojitost. ${ }^{\text {"53 }}$

Avšak s ještě šílenější představou se rozhodl přijít už během první světové války mladičký francouzský fyzik Louis de Broglie, který byl inspirován Einsteinovým mysteriózním světelným kvantem. Předsevzal si, že by totéž duální pojetí (předvídání a předpojetí) přeci mohlo fungovat i pro hmotu a částice z ní složené jako elektron nebo později proton. Provokující myšlenkový návrh o vlnové a korpuskulární povaze hmoty zformuloval podrobně ve své disertační práci, již se mu podařilo v roce 1924 obhájit (posvětil ji sám Einstein). Navrhl rovněž, jak dualismus hmoty experimentálně ověřit. ${ }^{54}$ Toto nové předporozumění se podařilo verifikovat v roce 1927 Clintonu J. Davissonovi a jeho asistentovi Lesterovi $\mathrm{H}$. Germerovi v USA, ${ }^{55}$ a nezávisle na nich také synovi slavného Josepha J. Thomsona Georgu P. Thomsonovi a jednomu z jeho studentů (Alexander Reid) v Anglii. ${ }^{56}$ Všichni tři obdrželi za své nevšední příspěvky Nobelovu cenu.

Později charakterizoval dobovou situaci klasicky uvažující Erwin Schrödinger, když mu došlo (a nejen jemu), že Thomson starší obdržel $\mathrm{v}$ roce 1906 Nobelovu cenu za to, že elektron je nedělitelná elementární částice a jeho syn George obdržel Nobelovu cenu v roce 1937 za to, že se chová

\footnotetext{
${ }^{51}$ William L. Bragg, „Electrons and Ether Waves,“ The Scientific Monthly 14, no. 2 (1922): 158.

${ }^{52}$ Arthur H. Compton, "A Quantum Theory of the Scattering of X-Rays by Light Elements,“ Physical Review 21, no. 5 (1923): 483-502.

${ }^{53}$ Albert Einstein, „Das Comptonsche Experiment. Ist die Wissenschaft um ihrer selbst willen da? / The Compton Experiment. Does Science Exist for Its Own Sake?,"in The Collected Papers of Albert Einstein. The Berlin Years: Writings \& Correspondence, April 1923 - May 1925, eds. Diana K. Buchwald et al. (Princeton, NJ: Princeton University Press, 2015), 233.

${ }^{54}$ Ke vzpomínkovému shrnutí viz Louis de Broglie, „The Reinterpretation of Wave Mechanics,“ Foundations of Physics 1, no. 1 (1970): 5-15. Dále viz Broglieho disertační práce: Louis de Broglie, Recherches sur la Théorie des Quanta. Annales de la Fondation Louis de Broglie (Paris: Universitè de Paris, 1924).

${ }^{55}$ Clinton J. Davisson and Lester H. Germer, „The Scattering of Electrons by a Single Crystal of Nickel,“ Nature 119, no. 2998 (1927): 558-60.

${ }^{56}$ George P. Thomson and Alexander Reid, „Diffraction of Cathode Rays by a Thin Film,“ Nature 119, no. 3007 (1927): 890.
} 
jako vlna. Schrödinger prý uštěpačně poznamenal, že by oba pány za jejich počiny „ještě před několika lety umístili do psychiatrické léčebny na pozorování jejich duševního stavu.. ${ }^{57} \mathrm{~V}$ roce 1935 také popsal, že z důsledků kvantové teorie pro každodenní život plynou rozmanité absurdity, např. to, že by kočka (de facto cokoliv a kdokoliv), když ji nevidíme (nedetekujeme), existovala v tzv. superpozici stavů kočky živé a současně mrtvé (živo-mrtvá). To považoval pochopitelně za nesmysl. ${ }^{58}$

\section{Atomární dění}

Vrátíme-li se zase o několik let zpět, fyzici si ve dvacátých letech kromě výše uvedeného dualismu předsevzali už konečně na základě nových předporozumění a předpojetí dořešit fungování atomárního dění ve starém Bohrově modelu atomu $\mathrm{z}$ roku 1913 . V něm přetrvávala řada problémů, poněvadž - navzdory jeho revolučnosti - byl podivným klasicko-kvantovým kočkopsem. Bohrovo předporozumění pro řešení vědeckých hlavolamů bylo už od mládí formováno interdisciplinárně a za použití záměrně rozporuplných nebo nekompatibilních př́stupů, a právě tímto neobvyklým metodickým způsobem si tehdy vytvořil vlastní pracovní model atomu. ${ }^{59}$ Do něho se proto nebál aplikovat zcela neslučitelný mix předpokladů, jednak některé klasické koncepty (orbit, dráha, rychlost) a pak mimo jiné mimořádně chytř̌e vypůjčenou Planckovu konstantu $\mathrm{z}$ úplně odlišné oblasti bádání na kvantování energie elektronů $\mathrm{v}$ atomových obalech. Podle Bohra byla Planckova konstanta - z hlediska klasických předpokladů - iracionální ${ }^{60}$

Nejdřive však v roce 1911/12 Ernest Rutherford, Bohrův mentor a brilantní experimentální radiofyzik $\mathrm{z}$ univerzitní laboratoře $\mathrm{v}$ Manchesteru, zveřejnil model atomu, který obsahoval drobounké kladně nabité jádro, v němž je však soustředěno $99,9 \%$ veškeré hmotnosti atomu, a kolem tohoto centra se $\mathrm{v}$ zatím nevyjasněných drahách pohybovaly záporně nabité elektrony (tzv. planetární model). Učebnicově řečeno: Rutherford se svými mladými asistenty Hansem W. Geigerem) a Ernestem Marsdenem objevil

\footnotetext{
${ }^{57}$ Erwin Schrödinger citován dle Ivan Štoll, Dějiny fyziky (Praha: Prometheus, 2009), 444.

${ }^{58}$ Jeho známý myšlenkový experiment s kočkou v krabici shrnutý do jednoho odstavce je sice složitější, ale důsledek stejný, více viz Erwin Schrödinger, „Die gegenwärtige Situation in der Quantenmechanik,“ Die Naturwissenschaften 23, no. 48, 49, 50 (1935): §5.

${ }^{59} \mathrm{~K}$ Bohrově myšlenkovému vývoji viz Grygar, Komplementární myšlení Nielse Bohra, 1. kap.

${ }^{60} \mathrm{~K}$ Bohrově práci viz Filip Grygar, „Historická, filosofická a fyzikální reflexe Bohrova převratného pojednání z roku 1913,“ Dějiny věd a techniky 46, č. 1 (2013): 3-26. Podrobně pak Bohr, Collected Works, vol. 2.
} 
jádro atomu na základě bombardování zlaté fólie částicemi alfa (kladně nabitá jádra prvku hélia), jež se od nepatrného jádra různě odrážely - dle předchozích propočtů a modelu atomu J. J. Thomsona by se možné částice procházející atomárním prostorem neměly odchylovat, a jestliže ano, tak jen velmi mírně. Rutherfordovi se tak svými pokusy podařilo vyvrátit předchozí modely atomu, např. tzv. pudinkový a saturnovský model. ${ }^{61}$

Naproti tomu fyzik a astronom Arthur Eddington tvrdil, že Rutherford jádro atomu neobjevil, nýbrž si jej na podkladě své úžasné představivosti a posléze prostřednictvím šikovně nastavených experimentů (a s pomocí pečlivě vytepané zlaté destičky do nejtenčí možné tlouštky) stvořil, podobně jako to dělá sochař, který se rozhodl pomocí vhodného sochařského náčiní vytesat do kamene svoji původní ideu, kupř́íkladu piety. ${ }^{62}$

Obě pozice jsou podle nás polovičaté. Hermeneuticky řečeno, Rutherford přistupoval ke svým pokusům (předsevzetím) s vystřelováním tisíců alfa částic na různé fólie (lehkých a těžkých prvků, jiných tlouštěk i s odlišně nastavenými sklony), jak na základě dosavadních modelů atomu a teorií (předvídání a předpojetí), tak s jeho proslulou schopností mente concipere. Marsden hovoří o Rutherfordově neortodoxních předvídáních jako predtuchách (hunches). ${ }^{63}$

Nobelista Rutherford, jenž byl v roce 1909 na vrcholu své zářné kariéry, po dlouhodobě prováděných pokusech se svými „hochy [boys]“64 věděl, že alfa částice vystř̌lované $\mathrm{z}$ trubičky (zdrojem vyzařování částic bylo radium) prochází fólií či vrstvami atomů lehkých prvků většinově zcela př́imočaře - jako by byly atomy zcela prázdným prostorem. Nepatrné prritahování záporně nabitými elektrony částicím alfa vůbec nepřekáží, nebot mají mnohonásobně vyšší hmotnost. U těžších prvků se však některé alfa částice začaly odchylovat $\mathrm{z}$ přímé dráhy mezi vyzařovaným zdrojem a zadním scintilačním detektorem či stínítkem, na němž po dopadu alfa částice zajiskrrí. ${ }^{65}$

${ }^{61} \mathrm{~K}$ předchozím koncepcím modelů atomu viz Grygar, „Historická, filozofická a fyzikální reflexe Bohrova převratného pojednání z roku 1913.“

${ }^{62}$ Arthur Eddington, The Philosophy of Physical Science (Ann Arborm, MI: University of Michigan Press, 1958), 109.

${ }^{63}$ Viz John B. Birk, ed., Rutherford at Manchester (New York, W. A. Benjamin, Inc., 1963), 8.

${ }^{64}$ John L. Heilbron, Ernest Rutherford: And the Eplosion of Atoms (Oxford: Oxford University Press, 2003), 105.

${ }^{65}$ Mladí fyzici Geiger s Marsdenem museli pracovat každý den mnoho hodin v temné komoře, kde pomocí mikroskopu sledovali, jak desítky tisíc částic alfa po dopadu na zadní scintilační stínítko zajiskří. Počítali je a rovněž zaznamenávali, jak se občas některá alfa částice pod různými úhly odchyluje od př́mé dráhy. Dále viz Edward N. da Costa Andrade, Rutherford and the Nature of the Atom (New York: Doubleday \& Company, Inc., 1964). 
Rutherforda tehdy napadla další - a nikoli poslední - fantastická myšlenka. Oproti jiným fyzikům, kteří prováděli podobné experimenty s rozptylem bombardovaných částic i v jiných laboratořích, ${ }^{66}$ vytušil, že by uvnitř atomů mohlo být ještě něco dalšího a drobného, co by teprve tvořilo většinovou atomární hmotnost a zřejmě i kladný náboj, jenž by byl př́činou onoho odchylování alfa částic. Bud' by se jednalo o nějakou jednu nepatrnou centrální částici anebo několik (pojem jádra začal Rutherford používat od roku 1912). Pokud by tomu tak bylo, pak by se některé vystřelované alfa částice procházející atomy zlata (nebo jiného těžkého prvku) už musely výrazně nejen odchylovat ze své prímočaré dráhy, ale dokonce se i vzácně od kovové fólie odrazit zpět kvůli obří síle odpuzování pocházející z daného centra či několika center (jádro zlata sice není větší než alfa částice, ale je padesátkrát těžší). To by však znamenalo uspořádat (předsevzetí) experimenty tak, aby byl scintilační detektor umístěn nikoli jen za pokusnou fólií, jak se to doposud v laboratořích dělalo, ale zcela nově (díky předtuše či novému předvídání) kolem dokola (včetně zahrnutí samotného zdroje vyzařování, pro který by byl $\mathrm{v}$ detektorovém stínítku vytvořen otvor).

Marsden vzpomíná, že Rutherford jim jeden den sdělil, jak mají experiment sofistikovaně uspořádat, a také jak byli po týdnu vyčerpávajícího pozorování překvapeni, když Rutherfordem předvídaný jev nakonec přeci jen zpozorovali, což mu okamžitě utíkali ohlásit. ${ }^{67} \mathrm{~V}$ upřesněných pokusech se zlatou fólií o tlouštce $0,00004 \mathrm{~cm}$ se prokázalo, že částice alfa, „přibližně 1 z 20000 , byly odchýleny v průměru až o 90 stupňủ. “" Takováto výrazná odchýlení a neprůchodnost fólií někteří vědci (např. J. J. Thomson) vykládali na základě svých předvídání a předpojetí jako náhodu, omyl nebo postupné nasčítání odchylek během pronikání alfa částice četnými vrstvami nahromaděných atomů zlata. Nicméně $v$ dalších pokusech se prokazatelně odhalilo, že čím těžší prvek byl bombardován, tím průkaznější bylo, že některé alfa částice byly odmrštěny dokonce zpět o $180^{\circ}$. To bylo neuvěřitelné, když

\footnotetext{
${ }^{66}$ Vyjděme např. z české zkušenosti. Historik fyziky Ivan Štoll uvádí, že podobné experimenty $s$ rozptylem částic i skrze dvě rozmanitě nastavované fólie prováděli v Praze na univerzitě už v roce 1906 experimentální fyzik Bohumil Kučera s Bohumilem Maškem. K tomu viz Ivan Štoll, Dějiny fyziky (Praha, Prometheus, 2009) 453. Jejich předsevzetím, předvídáním a předpojetím bylo pouze pečlivé zaznamenávání rozptylu alfa částic v různě nastavených pokusech, podobně jako to původně dělali pro Rutherforda jeho asistenti.

${ }^{67}$ Viz Birk, Rutherford at Manchester, 8.

${ }^{68}$ Ernest Rutherford, „The Scattering of $\alpha$ and $\beta$ Particles by Matter and the Structure of the Atom," Philosophical Magazine 21, no. 6 (1911): 669; Ernest Rutherford and Hans W. Geiger, "The Probability Variations in the Distribution of Alpha Particles," Philosophical Magazine Series 20, no. 6 (1910): 698-707.
} 
si uvědomíme, že velikost jádra je ve srovnání s obřím atomovým obalem asi jako zrnko písku umístěné uprostřed velké multifunkční haly. Pro Rutherforda to bylo ,jako kdybyste vystřelili patnáctipalcový náboj na list tenoučkého papíru a ten by se od něj odrazil zpět a zasáhl vás. “69

Jenže zásadní problém Rutherfordova modelu spočíval $\mathrm{v}$ tom, že by na podkladě klasických předporozumění (Maxwellových zákonů elektrodynamiky) nemohl reálně existovat. Záporně nabité elektrony by nebyly jen mocně přitahovány kladně nabitým jádrem (jako např. planety sluncem), nýbrž by také byly okamžitě urychlovány a padaly po spirále směrem $\mathrm{k}$ jádru, poněvadž by o své záhubě dávaly vědět prostřednictvím spojitého vyzáření své energie (elektromagnetických vln). Jenže $a$ ) elektrony takto nepadají do jádra, atomy s jádry i elektrony existují a $b$ ) atomy prvků jsou charakteristické skrze rozličné sady nespojitých detekovatelných čar (dané spektrum záření tvoří sérii určitelných frekvencí či vlnových délek).

$\mathrm{V}$ této dějinné situaci, kdy o Rutherfordův model atomu de facto nikdo nejevil zájem (ani on sám), nastoupil Bohr, jemuž byl nesmírně sympatický nejen šéf laboratoře Rutherford, s nímž se rychle spřátelil, ale též jeho nefunkční model - tomu Bohr doslova uvěřil s tím, že dosavadní teorie atomů bude muset projít radikální revizí (nové předvídání a předpojetí). Proto si předsevzal, že elektronům dovolí se pohybovat maximálně pouze po klasicky navržených a symetricky uspořádaných orbitech s pevně danou energií (počítal s klasickou rychlostí elektronů, jejich vzdálenostmi od jádra atd.), a pak se rozhodl, že jim umožní přeskakovat na vyšší anebo nižší energetickou hladinu atomu tak, že při každém přeskoku elektrony pohltí anebo vyzáří kvantum energie o určité vlnové délce (Bohr vyšel od nejjednoduššího atomu prvku vodíku). Tímto neuvěřitelným procesem kvantování energie elektronů $\mathrm{v}$ atomech ${ }^{70}$ pak vzniká u rozličných atomů prvků nespojité spektrum (tehdy bylo možné detekovat spektra několika prvků a jen série tvořící viditelné barevné čáry). Pro vysvětlení vztahu mezi vlnovými délkami (v té době ještě nepřesně naměřenými) a pozorovanými spektrálními čarami u atomu vodíku si zase Bohr fantasticky vypůjčil z jiné oblasti výzkumu (spektroskopie) jednoduchý Balmer-Rydbergův vztah či spektrální formuli. K tomu všemu brilantně navrhl několik klasicko-kvantových pravidel a ma-

\footnotetext{
${ }^{69}$ Ernest Rutherford, „Forty Years of Physics,“ in Background to Modern Science. Ten Lectures at Cambridge Arranged by the History of Science Committee 1936, eds. Joseph Needham and Walter Pagel (Cambridge: Cambridge University Press, 1938), 68.

${ }^{70}$ Je nutné poznamenat, že už před Bohrem docházelo k pokusům zavést do atomární oblasti kvantové podmínky. Více viz Grygar, „Historická, filozofická a fyzikální reflexe Bohrova převratného pojednání z roku 1913.“
} 
tematiku, aby jeho model atomu fungoval, třebaže Bohr věděl, že to není filosoficky správně. Nadto z hlediska fyzikálního nebyl model atomu ani dostatečně vysvětlen, musel být postupně vylepšován, dokud se $\mathrm{z}$ něj nestal model už jen čistě kvantový. ${ }^{71}$

Nicméně např. Einstein po celý život žasnul nad tím, že Bohrův zcela „nezajištěný a rozporuplný základ byl dostačující $\mathrm{k}$ tomu, aby umožnil muži Bohrova jedinečného instinktu a jemného citu objevit stěžejní zákony spektrálních čar a elektronových obalů atomů spolu s jejich významem pro chemii, to se mi jeví jako zázrak a jako zázrak se mi to jeví stejně tak i dnes. Toto je nejvyšší forma muzikálnosti ve sféře myšlení. “"2 Přesto jedním z dủležitých vylepšovatelů Bohrova prazvláštního modelu byl právě Einstein, jenž ve svém předporozumění bytí ve světě stále vycházel $z$ novověkých pozic ideálů vědy, a proto jej silně znepokojovalo náhodné nespojité přeskakování elektronů (změn energetických hladin) v atomu. Na základě tohoto postoje se rozhodl (předsevzetí), že se s tímto nekauzálním jevem musí něco udělat. V roce 1916/17 alespoň zavedl pro spontánní kvantové skoky statistické pravděpodobnosti, a ještě se mu tímto způsobem povedlo odvodit Planckův vyzařovací zákon. Leč záhy toho litoval, nepočítal totiž s tím, že užitím statistického charakteru pravděpodobnosti (nové předvídání a předpojetí) v této úzce vymezené oblasti zkoumání nastane nakonec principiální rozchod s klasickým determinismem př́rody i vesmíru. ${ }^{73}$

Dalším vylepšovatelem modelu byl de Broglie, jenž se rozhodl se svým duálním předporozuměním hmoty interpretovat pohyb elektronů jako částic po klasických drahách $\mathrm{v}$ atomu tak, že se elektron podobá zároveň reálnému stojatému vlnění u strun na houslích. Potom elektrony jako vlny reprezentují ten či onen orbit daný příslušnou vlnovou délkou (frekvencí). Fungovat to všechno podle něj mělo tak, že obdobně jako má každá ze strun svůj specifický zvuk nebo vibraci, mělo tomu tak být i s vibrujícími elektrony s jejich nespojitými energiemi v př́slušných stacionárních stavech. ${ }^{74}$ Avšak ani jeho vylepšení zdaleka nestačilo; mimo jiné neposkytovalo výklad

${ }^{71}$ Grygar, „Historická, filozofická a fyzikální reflexe Bohrova převratného pojednání z roku $1913 . “$

${ }^{72}$ Albert Einstein, „Autobiographical Notes, “in Albert Einstein: Philosopher-Scientist, ed. Paul A. Schilpp (New York: MJF Books, 1970), 46, 47.

${ }^{73}$ Např. Albert Einstein, „Zur Quantentheorie der Strahlung,“ Physikalische Gesellschaft Zürich. Mitteilungen 18 (1916): 47-62. Viz též Albert Einstein, „Quantentheorie des Strahlung,“ Physikalische Zeitschrift 18 (1917): 121-28.

${ }^{74} \mathrm{~K}$ př́ḱladům s vibrováním fixovaných strun či membrán viz L. de Broglie, An Introduction to the Study of Wave Mechanics (London: Methuen \& Co. 1930), 215-20. 
o pohybech či šíření vlno-částic $\mathrm{z}$ jednoho místa na jiné. K převratným událostem (nový rámec předporozumění) došlo v letech 1925 až 1927.

\section{Maticová a vlnová mechanika}

Obrátíme-li se k německým fyzikům, hlavně těm mladým, jako byl Heisenberg, reagovali na nové výzvy fyziky a atomárního dění snad nejradikálněji. Interpretovali vztah $\mathrm{k}$ tomu, že jest jim být ve světě, mimo jiné kulturním předporozuměním, $v$ němž se pohybovali po prohrané první světové válce, což ve svých ikonických závěrech rozvinul historik kvantové teorie a vědy Paul Forman. Upozorňoval na to, podobně jako Husserl, že intelektuální prostředí či obecně kultura poválečné a těžko se prosazující Výmarské republiky intenzivně zakoušela krizi vědy (i krizi Bohrova modelu atomu), negativní vztah vůči její exaktnosti, analytickému racionalismu, mechanistickým závěrům nebo technickým aplikacím na straně jedné, a na straně druhé zakoušela romantizující přilnutí k oslavě spontánního života, iracionální intuice, mystického prožitku nebo vztahu k celku a touhu po pradávných hodnotách či slávě Germánů.

Mladí a frustrovaní vědci se v prostředí Výmarské republiky, jež bylo podle nich nepřátelské vůči vědě a pokroku, snažili vyrovnat (předsevzetí) s tímto rozporem nejen kritikou, ale i ochotou opustit klasický ideál a platnost kauzality ve fyzice (zvláštní iracionalita kvanta akce jim proto nevadila). Chtěli se tak vypořádat s prohranou válkou, ovšem jinak než generace otců nebo starších vědců, kteří válku způsobili, podporovali nebo se do ní aktivně zapojili. Tento střet a zároveň kulturní nebo sociálně-politická spjatost $s$ minulostí vlastního národa odehrávající se v mysli každého Němce, měly podle Formana zásadní vliv (nikoli problematické vědecké či experimentální výsledky) na rozvoj a interpretaci kvantové teorie v Německu (nová předsevzetí, předvídání a předpojetí). A to z hlediska koncepce akauzality, antimaterialismu, antideterminismu, diskontinuity, názornosti nebo problému měření a role subjektu. ${ }^{75}$

Jedním z německých fyziků, kteří se ve zmatku doby ve svém bytí ideově či interpretačně hledali snad nejodvážněji a kteři se od počátku dvacátých let obří měrou zasloužili o novou fázi vývoje kvantové teorie odstřižením pupeční šňůry od teorie klasické, byl mladý Heisenberg, talentovaný vlas-

\footnotetext{
${ }^{75}$ Paul Forman, „Weimar Culture, Causality, and Quantum Theory, 1918-1927: Adaptation by German Physicists and Mathematicians to a Hostile Intelektual Environment, " Historical Studies in the Physical Sciences 3 (1971): 1-115.
} 
tenec, zručný klavírista, vůdce oddílu mladých skautů, hledač nových idejí, čtenář Platóna $\mathrm{v}$ originále a filosoficky zainteresovaný postdoktorand fyziky $\mathrm{u}$ významného vědce $\mathrm{v}$ Göttingen Maxe Borna. Heisenberg přistupoval $\mathrm{k}$ atomárnímu dění už jen čistě z předporozumění (předvídání a předpojetí) neklasického a matematicko-diskontinuitního (korpuskulárního) obrazu prŕrody, a jedině proto vytvořil (spoluvytvořil s göttingenskými kolegy) v roce 1925 první pilír kvantové teorie - maticovou mechaniku. Při jejím vzniku si prredsevzal matematicky vyjádřit atomární fyziku pouze na základě pozorovatelných veličin (a nahradit tak dosavadní Bohr-Sommerfeldovy kvantové podmínky klasicko-kvantového modelu atomu). Nejprve však byl silně zaskočen tím, že by v nové atomové fyzice nemusela platit taková samozřejmost jako obvyklý komutativní zákon, takže pro něj bylo zpočátku „dost neprŕjemné, že $Y \times X$ se nerovná $X \times Y{ }^{\text {“"76 }}$

Jelikož násobení matic není obecně komutativní, jsou vhodným nástrojem $\mathrm{k}$ reprezentaci kvantových operátorů, jež jsou v kvantové mechanice přiřazovány měřitelným veličinám. ${ }^{77}$ Maticová mechanika se tak opravdu díky Heisenbergovi zbavila klasických reprezentací či realistických vizualizací v atomárním dění (orbit, dráha, rychlost apod.) a přitom dokázala řešit predikce a intenzity spektrálních čar nebo některé neklasické podivnosti, např. spin elektronu (vnitřní moment hybnosti, obrazně řečeno jako to funguje u protočení dětské hračky „káči“ ve směru anebo proti směru hodinových ručiček). Byly zde však dva problémy: maticová mechanika jednak nezohledňovala v atomárním dění vlnové pojetí ani funkci času, a jednak pro tradiční fyzikální komunitu byla př́liš komplikovaná, abstraktní a nenázorná. ${ }^{78}$

To, co se nepodařilo opravit v atomárním dění de Brogliemu, Heisenbergovi a jiným, to se po nich podařilo do jisté míry doplnit Schrödingerovi;

${ }^{76}$ Werner Heisenberg, „Session VII,“ interview by Thomas S. Kuhn, American Institute of Physics - Oral History Interviews, February 22, 1963, https://www.aip.org/history-programs/ niels-bohr-library/oral-histories/4661-7; Heisenberg, Část a celek, 74-76.

${ }^{77}$ Kvantová teorie nepoužívá klasicky definované veličiny, nýbrž lineární operátory, cosi jako fyzikálně-matematickou „kuchařku“ nabízející více informací a možností, jak operovat s porozuměním a determinací veličin. Kvantové operátory dále ukázaly, že zkoumaná skutečnost je i produktem člověka, proto jej ve výzkumu přírody nemůžeme eliminovat, jak od počátku připomínal i Bohr.

${ }_{78}$ Werner Heisenberg, „Über quantentheoretische Umdeutung kinematischer und mechanischer Beziehungen,“ Zeitschrift für Physik 33 (1925): 879-93. Pro konečné ztvárnění maticové mechaniky viz Max Born and Pascual Jordan, „Zur Quantenmechanik, “ Zeitschrift für Physik 34 (1925): 858-88; dále také Max Born, Werner Heisenberg and Pascual Jordan, „Zur Quantenmechanik II,“ Zeitschrift für Physik 35, no. 8-9 (1926): 557-615. 
dalšímu slavnému vědci, rodilému Vídeňákovi, filosoficky zainteresovanému mysliteli přednášejícímu na univerzitě v Curychu. Schrödinger vycházel pouze $\mathrm{z}$ klasického a reálně-vlnového (kontinuálního) předporozumění (předvídání a předpojetí) přírody, a proto si předsevzal vytvořit čistě jen vlnovou mechaniku, druhý pilír kvantové teorie. Sice se nechal inspirovat Broglieho snahou o reálnou koncepci atomárního dění, ale vynechal zcela korpuskulární či nespojitý výklad elektronů (kvantové skoky mezi stacionárními stavy apod.), nahradil je tzv. vlnovými balíčky a nadto interpretoval vlnové uspořádání elektronů v atomu tak, jako je klasické elektromagnetické vlnění vysvětleno v Maxwellově teorii.

Vlnovou mechaniku, která podle něj popisovala hmotné vlnění v atomu, se mu podařilo sestrojit o vánočních svátcích roku 1925 ve švýcarském stř̌edisku Arosa, kam vyrazil se svojí inspirativní vídeňskou milenkou a o své vlnové koncepci pak v první polovině roku 1926 publikoval několik stěžejních statí. Vlnová mechanika se zavedenými terminologickými a matematickými nástroji (vlnová funkce $\Psi$ popisující matematicky elektron jako vlnu časovou i bezčasovou rovnicí, termín vlnový balík, vlnová mechanika apod.) byla pro širokou vědeckou komunitu jasná i názorná, a třebaže se nespoléhala na tradičně zavedené elektrony, poradila si matematicky i se spektrálními čárami vodíku a kromě jiného řešila nepostradatelnou funkci času, již nezahrnovala maticová mechanika. ${ }^{79}$

Podstatné zauzlení tohoto př́běhu však tkvělo $\mathrm{v}$ tom, že Heisenberg ani Schrödinger (a jejich urputní podporovatelé) se nechtěli vzdát svých jednostranných výkladů, o nichž se domnívali, že jsou dostačující pro komplexní vysvětlení atomárního dění, a nadto se o mechanice toho druhého nevyjadřovali nijak lichotivě. Ačkoliv Schrödinger v květnu 1926 ukázal, že samotné matematické formalismy obou mechanik jsou kompatibilní (nikoli fyzikálně a filosoficky) a poskytují stejné výsledky, vyvolalo to paradoxně u tvůrců a zastánců té či oné mechaniky ještě větší ideový, emoční i osobní spor. ${ }^{80}$ Ukázalo se za prvé, že matematika je sice krásným nástrojem k tomu,

\footnotetext{
${ }^{79}$ K období přelomu roku 1925 a 1926 z hlediska Schrödingera viz např. Walter Moore, Schrödinger. Life an Thought (Cambridge: Cambridge University Press, 1989), 194-95. První čtyři slavné studie pod názvem "Quantisierung als Eigenwertproblem“ vyšly v roce 1926 na pokračování v časopise v Annalen der Physik.

${ }^{80}$ Více viz Grygar, Komplementární myšlení Nielse Bohra, 3. kap. S názvem kvantová mechanika (Quantenmechanik) vystoupil Born, když se pokoušel s kolegy nahradit nedostačující klasickou mechaniku při vysvětlování prapodivného atomárního dění, Max Born, „Über Quantenmechanik,“ Zeitschrift für Physik, 26 (1924): 379-395. Tento titul potom začali fyzici společně s maticemi či rovnicemi a vektory používat ve výše uvedených článcích z roku 1925
} 
že se jí daří, jak píše Heisenberg, zamaskovat rozmanité paradoxy v matematickém aparátu, nicméně není spásonosná právě v ideových věcech. ${ }^{81}$ A za druhé, podstatné $\mathrm{v}$ tomto sporu se ukázaly být především neslučitelné předpoklady či předporozumění přírody, atomů a fyzikálních pojmů (předvídání a předpojetí), s nimiž oba fyzici i jejich spř́ízněnci přistupovali jak k ustavení obou mechanik, tak $\mathrm{k}$ jejich obhajobě a klamným pocitům o vyčerpávajícím porozumění atomárního dění, respektive přírody. Matematický génius kvantové teorie Paul Dirac poukazoval později na to, že „problém, jak získat tuto interpretaci, se ukázal být skoro obtížnější nežli správné vypracování daných rovnic." ${ }^{22}$

\section{Bohrovy diskuse se Schrödingerem a Heisenbergem}

Bohr oproti Heisenbergovi a Schrödingerovi přistupoval k řešení fyzikálních, a vůbec jakýchkoli otázek už dlouho s existenciálním předporozuměním, že jsme vždy již jako diváci a herci zapuštěni v jazyce a zároveň v existenci či bytí, jehož zakoušení se snažíme interpretovat prostřednictvím rozličných vědních oborů včetně filosofie. ${ }^{83}$ Nemilou situaci ve fyzikální komunitě si Bohr př̀edsevzal řešit $\mathrm{v}$ rámci nového předporozumění (předvídání a předpojetí), které začal na jaře 1927 explicitně nazývat komplementaritou.

Tento převratný epistemologický rámec myšlení (Bohr proto nikdy nepoužíval pro komplementaritu označení princip) dokáže doplňovat rovnocenně výlučné jazyky, deskripce, principy, neslučitelné teorie nebo paradoxní výsledky experimentů, tudíž i vlnový a korpuskulární výklad prŕrody, které se $\mathrm{v}$ klasické fyzice vysvětlovaly zcela odděleným způsobem. Neslučitelnost, na niž dával důraz, znamená, že z pojmu ,vlna“ neodvodíme „částici“ a naopak (výlučně nekauzální jsou rovněž experimenty pro pozorování bud’ vlnového anebo korpuskulárního chování kvantových systémů). Uvedené doplňování probíhá v naší hlavě, a nikoli v prŕrodě, a stejně tak to platí napřr. pro vzájemně výlučné percepce (nikoli optické klamy) „vázy“ a "profilů hlavy“ na slavné Rubinově váze. ${ }^{84} \mathrm{~V}$ Bohrově rámci komplemen-

a 1926; termín maticová mechanika (Matrizenmechanik, matrix mechanics) se začal používat patrně až v rozlišení od pozdější Schrödingerovy vlnové mechaniky.

${ }^{81}$ Werner Heisenberg, Fyzika a filosofie (Praha: Aurora, 2000), 17.

${ }^{82}$ Paul Dirac citován dle Abraham Pais, Niels Bohr's Times, in Physics, Philosophy and Polity (Oxford: Clarendon Press, 1993), 295-96.

${ }^{83}$ Grygar, Komplementární myšlení Nielse Bohra, 1. kap.

${ }^{84}$ Edgar Rubin, Visuell wahrgenommene Figuren. Studien in psychologischer Analyse mit 13 Abbildungen (Berlin: Gyldendalske Boghadnel, 1921), 247. 
tarity tak nejde o doplňování pouhých protikladů, jimiž jsou např. dvojice horký-studený, plus-minus, smrt-život aj., poněvadž protiklady se samozřejmě vždy již nějak vyžadují, jeden pól se nemůže vyskytovat bez druhého. Podobně spárované (nikoli komplementární) jsou dvojice veličin jako je rychlost a poloha, energie a hybnost atd., nebo naše prožitky (intencionální akty) a jejich obsahy (intencionální objekty) jako vidím viděné, vzpomínám vzpominané atd. ${ }^{85}$

Bohr se v patové situaci rozhodl pozvat počátkem ř́ina 1926 Schrödingera na týdenní návštěvu do Kodaně do Fyzikálního ústavu, aby jej přesvědčil mimo jiné o nutnosti doplnit jednostranné vlnové pojetí atomárního dění o neslučitelné pojetí korpuskulární. Jejich rozhovory trvaly od rána do noci a byly natolik vyčerpávající, že nebohý Schrödinger onemocněl a ulehl u Bohrů do postele (bydleli ve vile vedle Fyzikálního ústavu) ${ }^{86} \mathrm{Bohr}$ se tehdy snažil kolegu přesvědčit, že je nutné nahlížet atomární dění celkově již neklasickým zpơsobem, to znamenalo interpretovat rovnice vlnové mechaniky jinak, než prosazoval sám jejich tvưrce. Max Born totiž prokázal, že je nezbytné do vlnové mechaniky zavést statistickou či pravděpodobnostní interpretaci. Jinak řečeno Schrödingerova rovnice musí být nahlížena v novém předvídání a předpojetí jako formalismus popisující vlnu pravděpodobnostní, tj. určuje jen tzv. hustotu pravděpodobnosti výskytu částic, poněvadž experimentální výsledky poskytovaly pouze statistické kalkulace individuálních procesů změn a přechodů, ne nějaké pozorovatelné hmotné vlnění; nikoli reálný výklad vlnových funkcí. ${ }^{87}$ Nešlo se navíc obejít ani bez korpuskulárního předporozumění atomárního dění, experimentální výsledky byly i v této věci evidentní.

Schrödinger však stále lpěl na tom, že kvantové skoky jsou pouhým přežitkem a domníval se, že je lze nahradit koncentrovanými vlnovými balíčky ve prospěch spojitých přechodů mezi stabilními vlnovými stavy (stojaté hmotné vlny); jeho koncepce vlnové funkce tak měla podle něj postačovat ke komplexnímu vysvětlení (Bohrova) modelu atomu. ${ }^{88}$ Jenže

\footnotetext{
${ }^{85}$ Podrobně viz Grygar, Komplementární myšlení Nielse Bohra, 3. kap. Srov. Bohr, Collected Works, vol. 10.

${ }^{86}$ Podrobně viz Filip Grygar, „Ideová východiska kvantové teorie a Schrödingerova návštěva Kodaně v říjnu 1926," Československý časopis pro fyziku 71, č. 1 (2021): 56-63.

${ }^{87}$ Max Born, „Zur Quantenmechanik der Stoßvorgänge,“ Zeitschrift für Physik 38, no. 11-12 (1926): 803-27.

${ }^{88} \mathrm{~K}$ tomu viz Erwin Schrödinger, „The Continuous Transition from Micro- to MacroMechanics, "in Collected Papers on Wave Mechanics, ed. Erwin Schrödinger (London: Blackie \& Son Limited, 1928), 44.
} 
pak by podle Bohra nebylo možné zachovat Einsteinovo odvození Planckova vyzařovacího zákona; energie v atomu evidentně nabývá diskrétních hodnot, ty se spontánně mění a to opět nespojitě. Naproti tomu Schrödinger věril, že se jednou nakonec podaří i bez diskontinuitního předporozumění přírody aplikovat klasickou termodynamiku na hmotné vlnění a na Planckův vyzařovací zákon.

Heisenberg, který byl tehdy Bohrův asistent a přednášel (naučil se dánsky) v akademickém období 1926/27 na Kodaňské univerzitě, to všechno jako účastník pozoroval a vzpomínal na to, že Schrödinger nechtěl vidět diskontinuitní dění a Heisenberg rovněž správně vystihl, že ze zanícených disputací obou fyziků bylo možné vyčíst vžitá přesvědčení (předsevzetí, předvídání a předpojetí), která určovala to, jak se vytvářel nový výklad a matematický formalismus kvantové mechaniky. Podle něj nakonec Schrödinger zvolal, že „jestliže máme zůstat při tomto prokletém kvantovém skákání, pak lituji, že jsem se kdy zabýval kvantovou teorií," načež mu Bohr ihned horlivě odvětil tím, že „my ostatní jsme vám nesmírně vděční za to, že jste to udělal, nebot' vaše vlnová mechanika představuje ve své matematické jasnosti a jednoduchosti obrovský pokrok vzhledem $\mathrm{k}$ dosavadní formě kvantové mechaniky." ${ }^{\text {"89 }}$

Jelikož Heisenberg neměl v lásce vlnovou mechaniku, jistě tehdy tušil, že dalším pokusným králíkem k testování Bohrových ustavujících se komplementárních představ bude nepochybně on. Po odjezdu Schrödingera zakusil na vlastní kůži ještě urputnější Bohrovu argumentační smršt během dvou sérií diskusí. Bohr chodil z domova do ústavu bud' venkem anebo suterénní chodbou a pak vystoupal až nahoru do malé podkrovní bytové jednotky, kde tehdy Heisenberg bydlel (dnes tam je toaleta). Nezřídka dosti emočně vypjaté rozhovory probíhaly až do noci a někdy se Bohr vracel domů až nad ránem. Poté, co se Bohrovi nepodařilo Heisenberga přimět $\mathrm{k}$ tomu, že se bez vlnové mechaniky nelze obejít, odjel si raději odpočinout na dovolenou do Norska, aby si zde ujasnil svůj epistemologický rámec komplementarity. Heisenberg pak zase sám $\mathrm{v}$ klidu na základě svého diskontinuitního předporozumění prrírody vytvořil věhlasné relace neurčitosti (původně nepřesnosti; v anglicky mluvících zemích byl přidán název princip neurčitosti) pro spárované dvojice proměnných jako jsou hybnost a poloha, energie a čas, úhel a moment hybnosti apod. Ty byly v klasické fyzice uvažovány jakožto reprezentativně odpovídající př́rodě, slučitelné a s možností přesné determinace každé $\mathrm{z}$ nich současně, což je v kvantové mechanice, jak Heisenberg

${ }^{89}$ Heisenberg, Část a celek, 90-91. 
brilantně ukázal, ontologicky nemožné (proto se v ní mimo jiné používají lineární operátory nahrazující klasické pojetí reprezentace či proměnné). ${ }^{90}$

Druhá série vysilujících rozhovorů nastala po návratu Bohra $\mathrm{z}$ dovolené $v$ polovině března a trvala až do května. Bohr byl zpočátku naprosto unešený relacemi neurčitosti, ale postupně v Heisenbergově proslulém článku - již přijatém v časopise Zeitschrift für Physik - našel řadu nedostatků. Nejprve vyložil Heisenbergovy závěry komplementárně i z vlnového pojetí a nadto mu opravil některá zavádějící tvrzení včetně mylného vysvětlení obyčejného chodu mikroskopu (článek potom vyšel s vloženým dodatkem a poděkováním Bohrovi). Heisenberg, jak vzpomíná, se pod takovým emočním tlakem jednou dokonce rozplakal. ${ }^{91}$

\section{Závěrečné poznámky}

Na podzim v roce 1927 a na základě dosažených - nutno podotknout koncepčně nesourodých - výsledků v kvantové teorii Bohr prredstavil na dvou fyzikálních konferencích konaných $\mathrm{v}$ Como a Bruselu vlastní shrnující interpretaci kvantové teorie. Zásadní disputace, jež by bylo žádoucí rozebrat hermeneuticky, měl Bohrv Bruselu s Einsteinem (dále v roce 1935 a později), který nebyl př́tomen na setkání v Como. Jejich stěžejní filosoficko-fyzikální spory probíhaly, jak jinak, mimo oficiální jednání, v zákulisí nebo v době snídaně a Bohr všechny námitky svého geniálního prrítele krok po kroku vyvrátil. ${ }^{92}$

Heisenberg $v$ padesátých letech toto pro něj vyvrcholení vývoje kvantové teorie $\mathrm{v}$ roce 1927 začal nazývat kodaňskou interpretací, výkladem údajně jednotným, v jehož čele měl stát Bohr. Navíc od roku 1930 tvrdil, že jeho filosofie vědy je v jasném souladu s Bohrovou. Takový soulad však neexistuje, a nadto není vủbec zřejmé, co je správným nebo přesným obsahem bájné kodaňské interpretace. Heisenbergova předporozumění vedoucí k prosazování kodaňského výkladu jsou sice zajímavá, nicméně veskrze diskutabilní. Jeden $\mathrm{z}$ hlavních důvodů nejednotnosti a nesouladnosti v interpretaci kvantové mechaniky spočívá v tom, že spoluzakladatelé kvantové teorie měli odlišná

\footnotetext{
${ }^{90}$ Werner Heisenberg, „Über den anschaulichen Inhalt der quantentheoretischen Kinematik und Mechanik,"Zeitschrift für Physik 43, no. 3-4 (1927): 172-98.

${ }_{91}$ Werner Heisenberg, "Session VIII,“ interview by Thomas S. Kuhn, American Institute of Physics - Oral History Interviews, February 25, 1963, https://www.aip.org/history-programs/niels-bohr-library/oral-histories/4661-8; Podrobně k těmto diskusím viz Grygar, Komplementární myšlení Nielse Bohra, 3. kap.

${ }_{92}$ Grygar, Komplementární myšlení Nielse Bohra, 3. kap.
} 
filosofická, vědecká i kulturní předporozumění, s nimiž ke kvantové teorii přistupovali; stejně tak to platí pro Bohra a Heisenberga. ${ }^{93}$

Nadto další zásadní př́spěvky - zejména matematického rázu ke kvantové mechanice vznikaly v letech 1928-1933. Jmenujme zde proslulé a učebnicové publikace o principech kvantové mechaniky od Arnolda Sommerfelda, Maxe Borna a Pascuala Jordana, Jordana, Paula A. Diraca, Arthura Marche, Eugene P. Wignera, John von Neumanna, Enrico Fermiho nebo Wolfganga Pauliho. ${ }^{94} \mathrm{Na}$ těchto výsledcích a nových předporozuměních se už Bohr mnohdy ani nepodílel a kromě toho zastával ke kvantové teorii svůj originální filosofický postoj snažící se porozumět př́rodním fenoménům a lidskému životu v jejich komplementární komplexnosti. Vývoj kvantové teorie vedl ve třicátých letech také ke vzniku jaderné fyziky, která postupně objasnila dlouhodobě zkoumané jevy v oblasti radioaktivity a jaderných reakcí. Kvantová teorie dále sehrála zásadní roli při ustavení částicové fyziky zabývající se vznikem či složením hmoty, umožnila rozvoj výkonných urychlovačủ částic, jež kromě jiného poskytovaly velký zdroj radioizotopů, které se zase využívají ve výzkumu biologických struktur a v nukleární medicíně.

Jednou z ikonických publikací z roku 1930 jsou rovněž Heisenbergovy Chicagské přednášky $\mathrm{z}$ jeho návštěvy USA na jaře 1929. Právě v úvodu $\mathrm{k}$ nim rozšriřil zvěst o tom, že jsou ve shodě s Bohrovou koncepcí a zároveň neseny v kodaňském duchu kvantové teorie. Heisenberg $\mathrm{v}$ této publikaci do kvantové mechaniky kromě jiného zavedl mechanismus redukce vlnové funkce, který Bohrova filosofie vědy nepotřebovala. ${ }^{95}$ Tento dodnes používaný mechanismus už Heisenberg naznačil $\mathrm{v}$ původní verzi článku z roku 1927 o relacích neurčitosti, aby alespoň nějak vyhověl tlakům ze strany obhájců vlnové mechaniky a rovněž jejím oprávněným nárokům, jež mu dokládal i Bohr. Heisenberg se tehdy rozhodl vymyslet dílčí kompromisní řešení mezi maticovou a vlnovou mechanikou filosofickým způsobem tak, aby jeho koncepce př́rody $\mathrm{v}$ podobě diskontinuity, maticové mechaniky a relací neurčitosti nakonec přeci jen sehrávala v kvantové mechanice vůdčí

\footnotetext{
${ }^{93} \mathrm{~K}$ otázce kodaňské interpretace, Bohrově filosofii vědy a rozličným Heisenebergovým pohnutkám $\mathrm{k}$ tomu, proč začal používat problematický název kodaňská interpretace, viz Filip Grygar, „Werner Heisenberg, Niels Bohr a prríběh kodaňské interpretace,“ Teorie vědy / Theory of Science 39, č. 2 (2017): 207-38.

${ }_{94} \mathrm{~K}$ těmto zásadní příspěvkům ke kvantové mechanice viz Erhard Scheibe, The Logical Analysis of Quantum Mechanics (Oxford: Pergamon Press, 1973), 2.

${ }^{95}$ Werner Heisenberg, The Physical Principles of the Quantum Theory (Chicago: University of Chicago Press, 1930).
} 
roli (explicitní předvídání a předpojetí), jak se domníval. Tudíž vzhledem $\mathrm{k}$ tomu, že se díky Bornovi ukázalo, že Schrödingerův vlnový balíček je čistě pravděpodobnostní, Heisenberg v roce 1927 do svého slavného textu vložil tehdy nepodložené tvrzení, že „při každé lokalizaci či měření místa se takto vlnový balíček zredukuje opět na svoji původní velikost $\lambda .{ }^{\text {" } 96}$

Teprve až v Chicagských přednáškách svůj př́stup Heisenberg fyzikálně rozvedl, postuloval a hovořil o něm jako o druhu akce a pojem redukce vlnového balíku dal do závorky. ${ }^{97}$ Posléze se ujala terminologie redukce (kolaps) vlnové funkce (balíku) a tento nástroj, který následně zmatematizoval von Neumann (tzv. projekční postulát), se velmi rychle zabydlel v učebnicích kvantové mechaniky. Tudíž diskontinuita se podle Heisenberga realizuje vždy při mechanismu kolapsu vlnové funkce, což jednoduše řečeno znamená, že akt měření kvantového systému uskuteční přechod od možného (superpozice vlastních stavů měřeného systému), tj. spojitého, $\mathrm{k}$ faktickému (např. elektron zanechá viditelnou stopu na detektoru), tj. nespojitému. ${ }^{98}$ Heisenberg pak v roce 1955 tvrdil, že „je známé, že redukce vlnových balíčků se vždy objevovala v kodaňské interpretaci [...]." ${ }^{\text {"99 }}$ Legenda o Bohrově (a dalších fyziků) souladu s kodaňskou interpretací, potažmo dalšími výsledky, tak byla na světě, čehož Bohr litoval. To však neznamená, že pouze jeho interpretace kvantové mechaniky by měla být ta správná. Dosvědčuje to jen to, že interpretací kvantové teorie založených na různých předporozuměních je více, nikoli jedna.

Je důležité současně upozornit na to, že v komunitě kvantových teoretiků panovala nejen rozmanitá ideová, nýbrž také různá matematická předporozumění a př́ístupy $\mathrm{k}$ atomárnímu dění. Jmenujme alespoň některé zásadní matematické př́íspěvky, k nimž došlo po roce 1927. Dirac rozvinul maticovou a vlnovou mechaniku do podoby relativistické kvantové teorie elektronu, představil kvantovou elektrodynamiku či teorii pole, a dokonce již př̀edvídal antihmotu. Jeho slavná rovnice z roku 1928 zavedla do Schrö-

96 Heisenberg, „Über den anschaulichen Inhalt der quantentheoretischen Kinematik und Mechanik,“ 186. O této podivné redukci či větě si Bohr a další v ústavu mysleli, že jde o mystickou záležitost; podle autora tohoto článku se jedná o Heisenbergův mistrovský metafyzický trik, jenž dodnes v kvantové teorii funguje.

${ }^{97}$ Heisenberg, Physical Principles of the Quantum Theory, 39.

${ }^{98}$ Heisenberg, Fyzika a filosofie, 101.

${ }^{99}$ Werner Heisenberg, "The Development of the Interpretation of Quantum Theory," in Niels Bohr and the Development of Physics. Essays Dedicated to Niels Bohr on the Occasion of His Seventieth Birthday, eds. Wolfgang Pauli, Léon Rosenfeld, and Victor F. Weisskopf (London: Pergamon Press Ltd., 1955), 23. Více viz Grygar, „Werner Heisenberg, Niels Bohr a příběh kodaňské interpretace.“ Kolaps vlnové funkce je stejně metafyzický jako zákon setrvačnosti. 
dingerovy vlnové rovnice speciální relativitu (Diracova rovnice je vlnovou relativistickou rovnicí), přičemž je matematicky konzistentní jak s principy speciální relativity, tak s postuláty kvantové teorie. Dále to byl von Neumannn, který matematicky dokázal, že maticová a vlnová mechanika jsou nejen ekvivalentní, ale také že je lze zobecnit tak, že matice a vlnové funkce vytváři tzv. Hilbertův prostor. Von Neumann se pokusil matematicky formulovat i dodnes široce diskutovanou a stále kontroverzní otázku o roli měřicích př́strojů $\mathrm{v}$ průběhu fyzikálních pozorování.

$\mathrm{Na}$ základě hermeneutické fenomenologie a pomocí spletitých př́kladů $\mathrm{z}$ dějin vědy, a především vzniku kvantové teorie chtěl tento článek ilustrovat, že je nezbytné se v metodologii či filosofii vědy zabývat i podceňovanou otázkou bytostně implicitního a explicitního předporozumění. To prostřednictvím rámce předsevzetí, předvídání a předpojetí ustavuje rozmanité kulturní, sociální nebo psychologické motivace, které vedou k rozličným konkurenčním představám, přístupům a formalismům, s nimiž interpretujeme nejen v každodenním životě, nýbrž také ve vědeckých disciplínách to, co pro nás znamená být či bytí ve světě.

\section{Poděkování:}

Zvláštní poděkování náleží recenzentům tohoto článku za jejich věcné rady a doporučení na vylepšení obsahu či struktury textu.

\section{Bibliografie:}

Andrade, Edward N. da Costa. Rutherford and the Nature of the Atom. New York: Doubleday \& Company, Inc., 1964.

Augustinus, Aurelius. Vyznání. Praha: Kalich, 2006.

Birk, John B., ed. Rutherford at Manchester. New York: W. A. Benjamin, Inc., 1963.

Bohr, Niels. Collected Works. 13 vols. Amsterdam: North-Holland Publishing Company, 1972-2008.

Born, Max. „Über Quantenmechanik.“ Zeitschrift für Physik 26 (1924): 379-95. https://doi.org/10.1007/BF01327341.

Born, Max, and Pascual Jordan: „Zur Quantenmechanik.“ Zeitschrift für Physik 34 (1925): 858-88. https://doi.org/10.1007/BF01328531. 
Born, Max, Werner Heisenberg, and Pascual Jordan. „Zur Quantenmechanik II.“ Zeitschrift für Physik 35, no. 8-9 (1926): 557-615.

https://doi.org/10.1007/BF01379806.

Born, Max. „Zur Quantenmechanik der Stoßvorgänge.“ Zeitschrift für Physik 38, 11-12, 1926: 803-27. https://doi.org/10.1007/BF01397184.

Bragg, William L. „Electrons and Ether Waves.“ The Scientific Monthly 14, no. 2 (1922): 153-60.

Broglie, Louis de. „Recherches sur la Théorie des Quanta.“ Annales de la fondation Louis de Broglie. Paris: Universitè de Paris, 1924.

Broglie, Louis de. An Introduction to the Study of Wave Mechanics. London: Methuen \& Co. 1930.

Broglie, Louis de. „The Reinterpretation of Wave Mechanics.“ Foundations of Physics 1, no. 1 (1970): 5-15. https://doi.org/10.1007/BF00708650.

Compton, Arthur H. „A Quantum Theory of the Scattering of X-Rays by Light Elements." Physical Review 21, no. 5 (1923): 483-502. https://doi.org/10.1103/PhysRev.21.483.

Davisson, Clinton J., Lester H. Germer. „The Scattering of Electrons by a Single Crystal of Nickel.“ Nature 119, no. 2998 (1927): 558-60. https://doi.org/10.1038/119558a0.

Descartes, René. Meditace o první filosofii. Praha: Oikoymenh, 2003.

Einstein, Albert. „Theorie der Lichterzeugung und Lichtabsorption.“ Annalen der Physik 325, no. 6 (1906): 199-206. https://doi.org/10.1002/andp.19063250613.

Einstein, Albert. „Zum gegenwärtigen Stand des Strahlungsproblems.“ Physikalische Zeitschrift 10, no. 6 (1909): 185-93.

Einstein, Albert. „Über die Entwicklung unserer Anschauungen über das Wesen und die Konstitution der Strahlung." Physikalische Zeitschrift 10, no. 22 (1909): $817-25$.

Einstein, Albert. „Zur Quantentheorie der Strahlung.“ Physikalische Gesellschaft Zürich 18 (1916): 47-62.

Einstein, Albert. „Quantentheorie des Strahlung.“ Physikalische Zeitschrift 18 (1917): 121-28.

Einstein, Albert. „Das Comptonsche Experiment. Ist die Wissenschaft um ihrer selbst willen da? / The Compton Experiment. Does Science Exist for Its Own 
Sake?" In The Collected Papers of Albert Einstein. The Berlin years: Writings \& Correspondence, April 1923 - May 1925, edited by Diana K. Buchwald, József Illy, Ze'ev Rosenkranz, Tilman Sauer, and Osik Moses, 233. Princeton, NJ: Princeton University Press, 2015.

Einstein, Albert, Boris Podolsky, and Nathan Rosen. „Can Quantum-Mechanical Description of Physical Reality be Considered Complete?" Physical Review 47, no. 10 (1935): 777-80. https://doi.org/10.1103/PhysRev.47.777.

Einstein, Albert. „Autobiographical Notes.“ In Albert Einstein: PhilosopherScientist. Edited by Paul A. Schilpp. New York: MJF Books, 1970.

Forman, Paul. „Weimar Culture, Causality, and Quantum Theory, 1918-1927: Adaptation by German Physicists and Mathematicians to a Hostile Intelektual Environment." Historical Studies in the Physical Sciences 3 (1971): 1-115. https://doi.org/10.2307/27757315.

Galilei, Galileo. Prubír. Praha: Togga, 2020.

Galilei, Galileo. Discorsi e Dimostrazioni Mathematiche intormo à Due Nuove Scienze attenenti alla Meccanica, et ai Movimenti Locali. Leida: Ludovico Elzeviro, 1638.

Eddington, Arthur. The Philosophy of Physical Science. Ann Arborm, MI:

University of Michigan Press, 1958.

Gadamer, Hans-Georg. Člověk a řeč. Praha: Oikoymenh, 1999.

Grygar, Filip. Kritika založení galileovské vědy v Husserlově „Krizi evropských věd a transcendentální fenomenologii. “Červený Kostelec: Pavel Mervart, 2005.

Grygar, Filip. „Historická, filosofická a fyzikální reflexe Bohrova převratného pojednání z roku 1913.“ Dějiny věd a techniky 46, č. 1 (2013): 3-26.

Grygar, Filip. Komplementární myšlení Nielse Bohra v kontextu fyziky, filosofie a biologie. Červený Kostelec: Pavel Mervart, 2014.

Grygar, Filip. „Bohr's Complementarity Framework in Biosemiotics.“

Biosemiotics 10, no. 1 (2017): 33-55. https://doi.org/10.1007/s12304-016-9281-4.

Grygar, Filip. „Werner Heisenberg, Niels Bohr a př́iběh kodaňské interpretace.“ Teorie vědy / Theory of Science 39, č. 2 (2017): 207-38.

Grygar, Filip. „Odvrácená strana legendy: Otto Hahn v kontextu nacistického Německa.“ Teorie vědy / Theory of Science 41, č. 1 (2019): 59-110. 
Grygar, Filip. „Ideová východiska kvantové teorie a Schrödingerova návštěva Kodaně v ř́ijnu 1926.“ Československý časopis pro fyziku 71, č. 1 (2021): 56-63.

Heelan, Patrick A. „Afterword.“ In Hermeneutic Philosophy of Science, Van Gogh's Eyes, and God, Essays in honor of Patrick A. Heelan, S. J., edited by Babette E. Babich, 445-59. Dordrecht: Kluwer Academic Publishers, 2002. https://doi.org/10.1007/978-94-017-1767-0_39.

Heidegger, Martin. „Novověká matematická př́rodní věda.“ Scientia \& Philosophia, č. 6 (1994): 78-85.

Heidegger, Martin. „Gelassenheit - Zdrženlivá uvolněnost (30. října 1955).“ Filosofický časopis 49, č. 1 (2001): 70-79.

Heidegger, Martin. Bytí a čas. Praha: Oikoymenh, 2002.

Heidegger, Martin. Věda, technika a zamyšlení. Praha: Oikoymenh, 2004.

Heidegger, Martin. Věk obrazu světa. Praha: Oikoymenh, 2013.

Heilbron, John L. Ernest Rutherford: And the Eplosion of Atoms. Oxford: Oxford University Press, 2003.

Heisenberg, Werner. „Über quantentheoretische Umdeutung kinematischer und mechanischer Beziehungen." Zeitschrift für Physik 33 (1925): 879-93.

https://doi.org/10.1007/BF01328377.

Heisenberg, Werner. „Über den anschaulichen Inhalt der quantentheoretischen Kinematik und Mechanik." Zeitschrift für Physik 43, no. 3-4 (1927): 172-98. https://doi.org/10.1007/BF01397280.

Heisenberg, Werner. The Physical Principles of the Quantum Theory. Chicago: University of Chicago Press, 1930.

Heisenberg, Werner. „The Development of the Interpretation of Quantum Theory.“ In Niels Bohr and the Development of Physics. Essays Dedicated to Niels Bohr on the Occasion of His Seventieth Birthday, edited by Wolfgang Pauli, Léon Rosenfeld, and Victor F. Weisskopf, 12-29. London: Pergamon Press Ltd., 1955.

Heisenberg, Werner. "The Representation of Nature in Contemporary Physics.“ Daedalus 87, no. 3 (1958): 95-108.

Heisenberg, Werner. „Session VII.“ By Thomas S. Kuhn. American Institute of Physics - Oral History Interviews, February 22, 1963.

https://www.aip.org/history-programs/niels-bohr-library/oral-histories/4661-7. 
Heisenberg, Werner. „Session VIII.“ By Thomas S. Kuhn. American Institute of Physics - Oral History Interviews, February 25, 1963.

https://www.aip.org/history-programs/niels-bohr-library/oral-histories/4661-8.

Heisenberg, Werner. Část a celek - Rozhovory o atomové fyzice. Olomouc: Votobia, 1996.

Heisenberg, Werner. Fyzika a filosofie. Praha: Aurora, 2000.

Kuhn, Thomas. Struktura vědeckých revolucí. Praha: Oikoymenh, 1997.

Koyré, Alexandre. Metaphysics and Measurement - Essays in Scientific Revolution. Cambridge, MA: Harvard University Press, 1968.

Kvasz, Ladislav. „Galileovská fyzika ve světle Husserlovy fenomenologie.“

Filosofický časopis 48, č. 3 (2000): 373-99.

Mehra, Jagdish, and Helmut Rechenberg. The Historical Development of Quantum Theory. 6 vols. New York: Springer, 1982-2001.

Moore, Walter. Schrödinger. Life an Thought. Cambridge: Cambridge University Press, 1989.

Newton, Isaac. Matematické principy př́rodní filosofie. Praha: Fontes scientiae, 2020.

Novák, Aleš. „Heideggerův výklad pojmu mathéma a mathématického charakteru novověké vědy.“ Teorie vědy / Theory of Science 32, č. 1 (2010): 19-35.

Pais, Abraham. Niels Bohr's Times, in Physics, Philosophy and Polity. Oxford: Clarendon Press, 1993.

Planck, Max. „Über eine Verbesserung der Wien'schen Spektralgleichung.“

Verhandlungen der Deutschen Physikalischen Gesellschaft 2, no. 2 (1900): 202-4.

Planck, Max. „Zur Theorie des Gesetzes der Energieverteilung im

Normalspektrum." Verhandlungen der Deutschen Physikalischen Gesellschaft 2, no. 2 (1900): 237-45.

Planck, Max. „The Genesis and Present State of Development of the Quatnum Theory." Nobel Lecture, June 2, 1920.

https://www.nobelprize.org/prizes/physics/1918/planck/lecture/.

Petersen, Aage. „The Philosophy of Niels Bohr.“ Bulletin of the Atomic Scientists 14, no. 7, (1963): 8-14. https://doi.org/10.1080/00963402.1963.11454520.

Rubin, Edgar. Visuell wahrgenommene Figuren. Studien in psychologischer Analyse mit 13 Abbildungen. Berlin: Gyldendalske Boghadnel, 1921. 
Rutherford, Ernest, and Hans W. Geiger. „The Probability Variations in the Distribution of Alpha Particles." Philosophical Magazine Series 20, no. 6 (1910): 698-707. https://doi.org/10.1080/14786441008636955.

Rutherford, Ernest. „The Scattering of $\alpha$ and $\beta$ Particles by Matter and the Structure of the Atom." Philosophical Magazine 21, no. 6 (1911): 669-88. https://doi.org/10.1080/14786440508637080.

Rutherford, Ernest. „Forty Years of Physics.“ In Background to Modern Science. Ten Lectures at Cambridge Arranged by the History of Science Committee 1936, edited by Joseph Needham and Walter Pagel, 47-74. Cambridge: Cambridge University Press, 1938.

Scheibe, Erhard. The Logical Analysis of Quantum Mechanics. Oxford: Pergamon Press, 1973.

Schrödinger, Erwin. Collected Papers on Wave Mechanics. London: Blackie \& Son Limited, 1928. https://doi.org/10.1007/BF01491987.

Schrödinger, Erwin. „Die gegenwärtige Situation in der Quantenmechanik.“ Die Naturwissenschaften 23, no. 48, 49, 50 (1935): 807-12; 823-28; 844-49.

Štoll, Ivan. Dějiny fyziky. Praha: Prometheus, 2009.

Thomson, George P., and Alexander Reid. „Diffraction of Cathode Rays by a Thin Film." Nature 119, no. 3007 (1927): 890. https://doi.org/10.1038/119890a0.

Thomson, Joseph J. „Carriers of Negative Electricity.“ Nobel Lecture, December 11, 1906. https://www.nobelprize.org/uploads/2018/06/thomson-lecture.pdf. 